\title{
The Portfolio Rebalancing Effects of the ECB's Asset Purchase Programme*
}

\author{
Giovanna Bua and Peter G. Dunne \\ Central Bank of Ireland
}

\begin{abstract}
We explore the transmission of the ECB's Public Sector Asset Purchase Programme (PSPP) via portfolio rebalancing of investment funds and their investors. Using dynamic panel methods, we find that PSPP-holding funds rebalance towards bonds of non-EA banks and away from maturities targeted for purchase. Other fund types rebalance into assets with longer durations and towards non-EA bonds issued by both non-financial corporations and sovereigns. Significant effects appear after the scaling-up of the program. There is no evidence of rebalancing towards European equities. The pattern of rebalancing over the period examined reflects a reluctance to increase exposures to liabilities of EA banks and corporates.

JEL Codes: D72, H00, C72, C82.
\end{abstract}

\section{Introduction}

We extend and deepen the extant analysis of the effects of the Eurosystem's Extended Asset Purchase Programme (EAPP) by examining the portfolio rebalancing of investment funds and, indirectly, the behavior of fund investors who are responsible for the investment flows that determine redemption and issuance of fund units. Using a micro-panel econometric methodology, we identify how fund characteristics affect the heterogeneity of rebalancing behavior during the program.

${ }^{*}$ We thank Angelo Ranaldo, Joe McNeill, and Fergal McCann for helpful comments on an earlier draft. We are grateful to colleagues for their assistance with the funds data (including Brian Golden, Mark Bohan, Siobhan O'Connell, Padraig O'Brien, and Dermot Coates). Views expressed are those of the authors and do not necessarily represent the views of the Central Bank of Ireland or the ESCB. Author e-mails: giovanna.bua@centralbank.ie; peter.dunne@centralbank.ie. 
Portfolio rebalancing is one of several channels through which asset purchase programs are understood to transmit to economic effects. Asset purchases cause sellers to substitute into other asset classes. If investors have strong preferences for the holding of specific asset classes (and not just maturity-based preferred habitats as in Vayanos and Vila 2009), then there could be strong asset price effects from actual portfolio rebalancing. This raises the prospect of more widespread beneficial outcomes such as those outlined by Krishnamurthy and Vissing-Jorgensen (2011) 1

By purchasing long-term bonds, the central bank reduces the overall duration risk borne by banks and investors 2 Whether asset purchases have beneficial side effects (such as encouraging the taking of more risk or duration) is an open empirical question. Our analysis throws light on the risk/duration channel by examining changes in the term to maturity of assets held 3

Portfolio rebalancing away from euro-area (EA) assets and into foreign-issued assets may produce beneficial effects through an exchange rate channel. Demertzis and Wolff (2016) suggest that there has been a strong effect from asset purchases on the value of the euro 4 The current analysis does not attempt to identify

\footnotetext{
${ }^{1} \mathrm{~A}$ potential beneficial outcome from EAPP would be higher-priced equity markets which would drive down the cost of equity capital. (Analysis provided in the European Central Bank Economic Bulletin in 2015 finds little evidence of expected improvements in earnings/dividends following the initial phase of EAPP, so buoyant equity markets probably reflect asset purchase effects acting through increased risk appetite and lower discount rates).

${ }^{2}$ This also demonstrates its commitment to lower rates for longer (see, for example, Eggertsson and Woodford 2003).

${ }^{3}$ Financial stability concerns emerge (and a risk channel arises) if the program encourages holders to switch to high-risk assets and greater leverage as in Woodford (2012) and Coimbra and Rey (2016), as well as in taking on more liquidity risk as described by Stein (2014).

The theoretical work of Brunnermeier and Sannikov (2014) outlines more specific mechanisms for the transmission of such risks. Valiente (2015) also mentions the effects of the purchases on liquidity and financial plumbing. Evidence for these broader channels is beyond our focus.

${ }^{4}$ A January 2017 report, Deutsche Bundesbank (2017), also contributes evidence of such effects but concludes that they do not go significantly beyond the announcement effects of the program. The bulletin also highlights the fact that exchange rate effects are very difficult to disentangle from the effects of other monetary policy actions (e.g., changes in the rate earned on funds at the deposit
} 
exchange rate effects directly, but it provides evidence of significant movements into foreign assets.

To assess portfolio rebalancing effects, we principally examine the net purchases of assets acquired by investment funds. Since we focus on actual portfolio choices of individual funds, rather than on broad financial accounts sectors, our analysis is distinctly different from that of Albertazzi, Becker, and Boucinha (2016) and Koijen et al. (2017). These studies provide an important wide-angle view of portfolio rebalancing effects between broad sectors. Our more microfocused analysis can account for heterogeneity in responses to asset purchases across the sector and control for the extent of individual exposures to the policy.

By analyzing funds' net purchases of assets, as distinct from changes in the value of their holdings, it is possible to identify active rebalancing behavior as distinct from passive rebalancing as described in Bubeck, Habib, and Manganelli (2017) (this was not possible, for example, in the analysis of Joyce et al. 2011). Since funds can be heavily mandated to hold certain types of assets, we also explore whether some of the adjustment to the asset purchase program is shared by fund investors. This is achieved through an analysis of redemptions and issues. The detailed information about the strategies of funds in our sample also helps us to disregard funds that do not have the flexibility to adjust in response to the program (e.g., exchange-traded funds and index trackers). The analysis of this detailed data should enable an identification of portfolio rebalancing effects if they in fact exist.

While our analysis is entirely focused on the shadow banking sector within one country, we cover a large fraction of all euroarea investment fund activity (i.e., roughly 17 percent of total assets under management in the region). This focus is warranted since the sector has grown significantly during the period covered by the asset purchase program and it is a sector that is not as well understoodand not as well regulated - as the traditional banking sector. There is some evidence that banks have been an important channel for the transmission of effects from asset purchases (e.g., Altavilla, Canova, and Ciccarelli 2016; Altavilla, Boucinha, and Peydró 2017;

facility), complex market expectations adjustments in response to signaling, and policy initiatives outside the EA (e.g., tightening in the United States). 
and Carpinelli and Crosignani 2017), but we do not uncover strong links between our sample of investment funds and EA banks.

We employ a dynamic panel regression approach taking full advantage of the large cross-sectional sample of funds while controlling for individual differences that are unrelated to the EAPP program. This methodology circumvents violations of classical regression conditions required to deliver unbiased estimates of effects. We also control for the fundamental determinants of rebalancing associated with fluctuations in macroeconomic variables.

Our results provide evidence of significant rebalancing towards bonds issued by deposit-taking corporations but only after the pace of purchases was raised from $€ 60-€ 80$ billion per month. We find that investors rebalance away from funds focused on holding the assets targeted by the purchase program (in the case of EA government bonds, there is a move into shorter maturities - those not eligible for purchase under the EAPP). In terms of the maturities and currencies of newly purchased assets, we observe a move into non-PSPP assets with longer maturities, away from assets denominated in euros and into foreign-issued fixed-income assets. We find little evidence of a rebalancing towards equities.

It is important at the outset to acknowledge that heterogeneous views exist about the likely success, adequacy, and legitimacy of the EAPP5 Advocates for the program cite the likely tangible improvements in fiscal sustainability that would result from reductions in term and risk premiums. These would ultimately sow the seeds of future growth and inflation. Opponents are of the view that the purchase program (in conjunction with other ECB initiatives such as lending operations and Outright Monetary Transactions) might produce excessive risk-taking and reduce incentives to make structural reforms within the banking sector and in fiscal policy. This

\footnotetext{
${ }^{5}$ Firstly, Eggertsson and Woodford (2003) provide irrelevance propositions for certain channels of such policies. Secondly, Ball et al. (2017) argue that the policy is too timidly applied and should be extended to the purchase of equities and combined with a higher target for inflation. Thirdly, previous bond-buying policies have been challenged in constitutional courts. The lawmaker Peter Gauweiler from the Christian Social Union party in Bavaria took a case to Germany's Federal Constitutional Court in 2013/14 concerning the legitimacy of the Outright Monetary Transactions program.
} 
may contribute to lower expected long-term growth and increased future instability.

Assessing the merits of these opposing views is beyond the scope of our analysis except in respect to how investor behavior can be used to infer a willingness to bet on the success of the program. Portfolio choices reflect changes in risk aversion, investor perceptions of likely future risk exposures, and views about the relative future growth prospects of different economic sectors and economies. A valid inference from the revealed preference of investment funds (and investors) for the increased holding of non-euro-denominated assets is that there is some reluctance to bet on the efficacy of the asset purchase program. This is of course a sample-specific result.

The paper is organized as follows. In the following two sections we discuss the modalities and operation of the purchase program so far and consider related literature. This is followed by a detailed discussion of the econometric specification we use to identify effects of the purchase program. We then consider the data and results. This is followed by a discussion of robustness analysis and conclusions.

\section{The Extended Asset Purchase Programme So Far}

The Eurosystem's Extended Asset Purchase Programme was announced on January 22, 2015. The announcement was, to some extent, expected since normal policy tools (and some non-standard measures) had already reached the limits of their effectiveness. There were significant repayments of funding obtained in previous longterm refinancing operations (LTROs with three-year term) coinciding with the first of two new targeted long-term refinancing operations (TLTROs), and it was feared in some quarters that TLTROs would be used as replacement funding rather than for new lending 6 Macroeconomic conditions had also remained subdued, and actual and expected inflation were well below target. The headline rate of inflation had remained stubbornly below 1 percent throughout

\footnotetext{
${ }^{6}$ Early repayment of funding obtained through three-year LTROs is discussed in box 3 of the February Monthly Bulletin of ECB (2013). Andrade et al. (2017) find that the three-year LTROs supported lending levels (they study the case of French banks). The Fitch rating agency issued a statement in October 2014 expressing a view that TLTROs would continue to ease funding conditions but would be unlikely to affect lending.
} 
2014, and it reached a low of 0.3 percent in November $(0.7$ percent if energy and food were excluded).

So conditions were ripe for a further extension of non-standard measures into a full-blown quantitative easing (QE) program through direct purchases of assets. The main component of this has been the Public Sector Purchase Programme (PSPP). At the time of the initial announcement, the Eurosystem made a commitment to purchase more than $€ 1$ trillion of securities over an eighteen-month period. In December 2015 the termination date of the program was extended from September 2016 to March 2017 and more assets were included in the purchasable category (i.e., regional and local government bonds). In March 2016 the size of the program was scaled up from $€ 60-€ 80$ billion per month. These changes were combined with two adjustments in the deposit facility rate (firstly, in December 2015 to -30 basis points and then in March 2016 to -40 basis points), which also broadened the universe of assets that could be bought.

The program was further extended to include investment-grade corporate bonds in March 2016. By the end of 2016, the Eurosystem's balance sheet contained €1,654 billion of assets for monetary policy purposes, and this included a €105 billion legacy from the Securities Markets Programme (specifically, government bonds issued by Greece, Ireland, Italy, Portugal, and Spain) 7 By the end of April 2017, the ECB had purchased about $€ 1.5$ trillion under the PSPP component of the EAPP. Approximately $€ 1.3$ trillion of this consists of national government and agency bonds (see figure 1). The ABS and CBPP3 elements remain small, at roughly €24 and €216 billion by the end of April 2017.

In terms of the modalities of the program, the PSPP is split between government (central and local) and supranational in an 88 percent to 12 percent ratio. The capital key is used to target interventions across the issuer countries. This implies that countries with large GDP, large populations, and smaller national debt levels are

\footnotetext{
${ }^{7}$ The SMP was terminated on September 6, 2012 at the same time that technical features of Outright Monetary Transactions (OMT) measures were announced. SMP securities are held until maturity, and the outstanding stock from this program declined due to redemptions at a rate of about $€ 20$ billion per year.
} 


\section{Figure 1. Eurosystem Holdings under the Expanded Asset Purchase Programme}

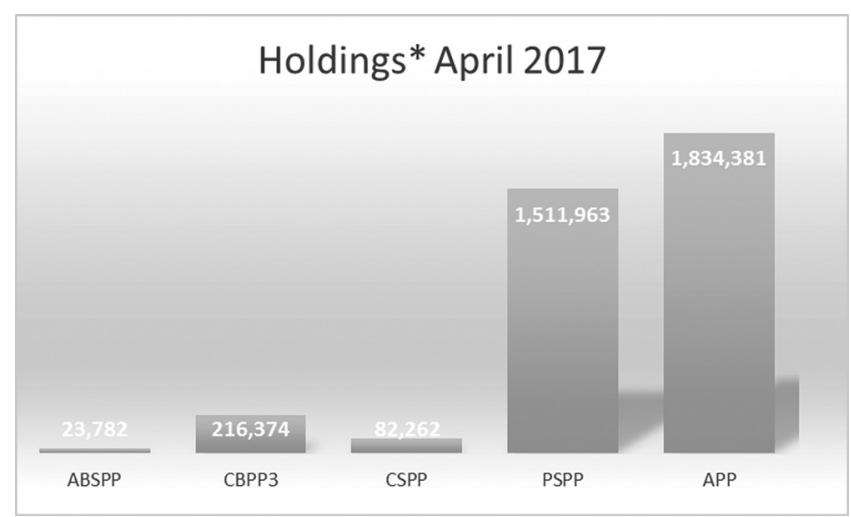

disproportionately affected by the purchases relative to outstanding debt. Bonds purchased must be $\mathrm{BBB}$ or better (i.e., at least investment grade) with maturities between two and thirty years. Purchases cannot exceed 33 percent of the outstanding issued debt of a sovereign and cannot exceed 25 percent of a particular issue. A condition applied to purchases, until its removal in December 2016, was that the yield to maturity of the purchased assets had to exceed the ECB's deposit facility rate at the time of purchase.

\section{Literature}

Much of the empirical research on the effects of asset purchases by central banks has focused on the immediate (flow) and persistent (stock) price effects (see Gagnon et al. 2010, 2011; Christensen and Rudebusch 2012; D'Amico et al. 2012; Joyce and Tonks 2012; D'Amico and King 2013; Altavilla, Carboni, and Motto 2015; Andrade et al. 2016; Eser and Schwaab 2016; Haldane et al. 2016; and DeSantis and Holm-Hadulla 2017). The exchange rate effects are examined by Glick and Leduc (2013). Volatility effects of QE have been analyzed by Bollerslev, Tauchen, and Zhou (2009), while equity price effects and corporate bond spreads are examined in Benford et al. (2009). The wider macroeconomic effects have been analyzed 
by, for example, Baumeister and Benati (2013), Weale and Wieladek (2014), and Engen, Laubach, and Reifschneider (2015).

There are relatively few papers that have tried to get insights into the portfolio rebalancing process by looking directly at the portfolio allocation decisions of financial intermediaries. Most portfolio rebalancing studies focus on flow-of-funds (financial accounts) sectors, including the investment fund category (e.g., Carpenter et al. 2013 and Hogen and Saito 2014). Joyce, Liu, and Tonks (2015) extend such an analysis to explore the heterogeneous impact of $\mathrm{QE}$ on insurance companies and pension funds based on fund characteristics. Fratzscher, Lo Duca, and Straub (2016) conduct an analysis of the international spillover effects of EA unconventional monetary policy (UMP), up to the end of 2012, using daily investment fund flows. This is based on a fraction of flows based on funds sampled for the EPFR data set (Emerging Portfolio Fund Research). These authors find that UMPs led to a rise in global markets through increased confidence and lower risk premiums. Excluding the announcement of OMT, most UMPs led to some weakening of the euro. Overall they found little evidence of portfolio rebalancing effects through international investment flows. Bubeck, Habib, and Manganelli (2017) also utilize the EPFR data source to assess portfolio rebalancing effects in response to euro-area monetary policy actions and find muted active responses but strong passive effects due to price and exchange rate outcomes.

Carpenter et al. (2015) find that sellers to the Federal Reserve were mainly households and other non-bank financial institutions comprising hedge funds, broker-dealers, and insurance companies. Those who sold to the Federal Reserve subsequently purchased corporate bonds. Hogen and Saito (2014) find that Japanese banks and foreign investors were the largest sellers of government bonds to the Bank of Japan and rebalanced towards bank loans, equity securities, and corporate bonds. The micro-level analysis of Joyce, Liu, and Tonks (2015) indicates that sales of U.K. gilts to the Bank of England by U.K. insurance companies and pension funds gave rise to reinvestment in corporate bonds. It is worth mentioning that Joyce, Liu, and Tonks (2015) do not possess the transactions data for the ICPF entities and rely on the change in value of the holdings. They could therefore be identifying a valuation effect rather than a change in portfolio composition. 
Another literature examines the impact of asset purchases on bank lending and profitability. Altavilla, Canova, and Ciccarelli (2016) uncover significant bank lending effects for the case of TLTRO and APP measures in the long run, while Carpinelli and Crosignani (2017) find a positive effect of LTROs (those with three-year term) specifically for banks hit by funding dry-ups. The strength of such effects of course depends on the health and resilience of banks, the regulatory environment, and the economic conditions in the markets into which banks traditionally lend (see Altavilla, Pagano, and Simonelli 2017; Bergant 2017; and Carpinelli and Crosignani 2017). An important point made by Valiante (2015) is that the low interest rate environment (and quantitative easing itself) may have produced challenging conditions for bank profitability. This is challenged by Altavilla, Boucinha, and Peydró (2017), who consider a wider tradeoff of effects and find that a decrease in short-term interest rates does not necessarily imply lower bank profitability overall. However, there remains some concern, based on squeezed net interest margins at low rates and at longer maturities, about the ability to engage in profitable and prudent lending. It is therefore valid to question whether banks alone can be relied upon to be the sole conduit of unconventional monetary policy effects.

Two recent papers on portfolio rebalancing as a result of the ECB's Extended Asset Purchase Programme include Albertazzi, Becker, and Boucinha (2016) and Koijen et al. (2017). In Koijen et al. (2017), the effects of the EAPP have been analyzed for broad sectors by using the holdings data of households and institutional investors. Their results so far only pertain to the period from 2013:Q4 to 2015:Q4. They examine how rebalancing of portfolios affects risk and duration exposures.

They find that there is a strong home bias in holdings of PSPP assets by vulnerable countries for all sectors (this is similar to findings by Hau and Lai 2016). Banks in vulnerable countries are therefore disproportionately exposed to sovereign risk. The significant results concerning responses to the EAPP purchases can be described as follows: (i) foreign holders were most elastic in their response to the program, (ii) the ECB buys 1.5 percent of duration risk each month and reduces risk mismatch, (iii) there has been a large reduction in debt issuance by banks in the euro area - such bonds were held by foreign and vulnerable-country banks, and (iv) 
the impact on EAPP asset prices has been 13 basis points but with a lot of heterogeneity across country of issuance and maturities. Our analysis is not as wide ranging as theirs, but it concerns a more detailed examination at a micro-level where cross-holdings are less likely to confound the results.

Albertazzi, Becker, and Boucinha (2016) examine the portfolio rebalancing of broad sectors (based on national financial accounts sectors) using an identification based on the size of the valuation increase experienced at the start of the EAPP. In the regression exercise, the weight of specific securities in sectoral portfolios is interacted with the price change of the security and this is, in turn, interacted with a dummy for the post-EAPP implementation period. They focus attention on newly issued debt securities. This is warranted because there must be equality in the rebalancing across investor groupings when the full population of investors is examined. Albertazzi, Becker, and Boucinha (2016) also consider the change in risk (measured by ratings and residual maturity). They compare the effects of EAPP across vulnerable and less vulnerable euro-area countries.

While Albertazzi, Becker, and Boucinha (2016) find no statistically significant relationship between portfolio rebalancing patterns across sectors due to the extent of exposure to initial APP effects for the euro area as a whole, they do in fact find a relationship for sectors in "the more vulnerable countries" where more credit risk and increased exposure to non-financial corporation (NFC) debt is found. They also find that banks that were most affected by APP (located in less vulnerable countries) increased their lending to NFCs and lowered the price of their credit to some sectors.

In our analysis, the question addressed is a bit different from Albertazzi, Becker, and Boucinha (2016). We examine how the fundlevel portfolios within one sector (investment funds) domiciled in one country have adjusted when the supply of one asset class is reduced. There is a wide variety of assets that are not accounted for by the portfolios we examine (i.e., we don't have the entire universe of assets in our study and we do not have the entire population of investors). Since the value of many assets continually fluctuates, funds will rebalance portfolios to adjust their ex ante exposures. Also, since values depend on the discounted value of returns - and these have quite variable fundamental determinants - it is possible to have large 
valuation changes within a sector portfolio that is unrelated to the supply of securities in circulation. In this context unanticipated losses on existing holdings will often be a primary determinant of future rebalancing behavior. Such confounding effects are, for example, likely to pervade the analysis of Albertazzi, Becker, and Boucinha (2016). Our approach avoids much of this spurious effect by focusing on net purchases. We also control for the fundamental determinants of valuation associated with fluctuations in macro variables. These are now outlined as part of our modeling approach.

\section{Model}

Our aim is to examine how the ECB's QE policy affected the withinsector rebalancing of investment funds (IFs). To this end, we focus on three different dimensions of portfolio composition, and we allow for heterogeneities in the response to $\mathrm{QE}$ amongst different types of funds according to a broad set of fund characteristics.

We estimate the following panel regressions:

$$
\begin{aligned}
& x_{i t}=\alpha_{i}+\gamma x_{i t-1} \\
& +\phi_{1} Q E \_ \text {antic }+\phi_{2} Q E \_ \text {first }+\phi_{3} Q E \_ \text {second } \\
& +\beta_{1} \text { Debt_net }_{t}+\beta_{2} \text { fin_control }_{j t} \\
& +\epsilon_{i t} \\
& l x_{i t}=\alpha_{i}+\gamma x_{i t-1} \\
& +\phi_{1} Q E \_ \text {_antic }+\phi_{2} Q E_{-} \text {first }+\phi_{3} Q E \_ \text {second } \\
& +\delta_{1} Q E_{-} a n t i c * F_{\text {und_charact }}{ }_{j i t} \\
& +\delta_{2} Q E_{-} \text {first } * \text { Fund_charact }{ }_{j i t} \\
& +\delta_{3} Q E \_s e c o n d * \text { Fund_charact }{ }_{j i t} \\
& +\beta_{1} \text { Debt_net }_{t}+\beta_{2} \text { fin_control }_{j t} \\
& +\beta_{3} \text { Fund_charact }_{j i t} \\
& +\epsilon_{i t} \text {, }
\end{aligned}
$$

where the dependent variable is the portfolio proportion of some asset class stated in percentage points for each investment fund 
$i$ and for quarter $t$. The assets are categorized into subsets along three dimensions of portfolio composition: (i) "Type and/or Issuer" of the asset; (ii) "Original Maturity" of the asset; and (iii) "Currency of Denomination" of the asset at the time of issue. The first of these broad categories is further subdivided into cash; equity issued by deposit-taking corporations; equity issued by other institutions; derivatives; security borrowing; overdrafts; other assets; bonds issued by governments; bonds issued by deposit-taking corporations; bonds issued by non-financial corporations; bonds issued by money market funds, IFs, or financial vehicle corporations; and bonds issued by other entities not already mentioned. The "Original Maturity" category is subdivided into assets with term to maturity less than one year, assets with term to maturity between one and two years, assets with term to maturity greater than two years, and assets with no planned term to maturity. For the final broad category, "Currency of Denomination," we subdivide into the three main currencies: USD, euros, and GBP.

To obtain a comprehensive overview of the dynamics of portfolio composition, we examine both the end-quarter stock positions and the within-quarter flows (i.e., transactions/net purchases expressed as a percentage of total assets) for each asset class. The stock position is subject to revaluation effects, and these tend to dominate the rebalancing effects. Purchases and sales of assets are recorded at market value at the time of the transactions so we can rely on the difference between gross buy and sell transactions to reflect portfolio rebalancing net of revaluations 8

In the first regression, we relate the portfolio rebalancing variable to QE dummy variables, namely, QE_antic, QE_first, and $Q E \_s e c o n d$. These dummy variables select the following time periods, respectively, for which QE effects (or the effects of its anticipation) are estimated: 2014:Q4, from 2015:Q1 to 2016:Q1, and from

\footnotetext{
${ }^{8}$ In particular, the stock is the share of asset class $x$ that the fund $i$ invests at the end of period $t$ over total assets of fund $i$ at the end of period $t$. The flow is the share of net transactions for asset class $x$ at the end of period $t$ for fund $i$ over total assets at the beginning of period $t$ for fund $i$. Net transactions are the market value of purchases and sales of a security on the dates of each transaction. A purchase implies an increase in the position, and sales imply a decrease in the position. Short-selling a security is a decrease in position (i.e., sale).
} 
2016:Q2 to 2016:Q3, respectively 9 Following the work by Carpenter et al. (2013) and Joyce, Liu, and Tonks (2015) and to control for non-QE macroeconomic contributors to portfolio rebalancing as well as supply-side effects of new issuances, we include the following explanatory variables in the regressions: (i) the net issuance of debt in the euro area in billions (Debt_net) and (ii) the following list of macroeconomic controls (collectively denoted fin_control ${ }_{j t}$ ): the U.S. ten-year Treasury yield adjusted to constant maturity (US_long_yield), the ten-year corporate spread (us_corp_spread2), and the VIX (us_vix_vol).

In the second regression, we add the interaction of $\mathrm{QE}$ variables with specific fund characteristics (Fund_charact ${ }_{i t}$ ), which are investor withdrawals relative to beginning-of-period net asset value (NAV) (redeem_nav) and investment inflows relative to beginningof-period NAV (issuance_nav), the fund leverage as a proportion of NAV (leverage_nav), and the average of sales and purchases of securities relative to NAV (turnover_nav) 10

We retain for analysis only those funds that are actively managed, and we exclude those funds that have a daily turnover relative to net asset value in excess of 17 percent. This is to avoid the inclusion of funds that engage in high-frequency trading 11 In order to ease the interpretation of the results, all the variables are centered around the pre-QE period average (2014:Q1-2014:Q3) 12

\footnotetext{
${ }^{9}$ Recall, the combined monthly purchases of private and public securities consisted of $€ 60$ billion from March 2015 up until March 2016. Starting in April 2016, the monthly purchase increased to $€ 80$ billion on average.

${ }^{10} \mathrm{We}$ also try to interact the following fund characteristics which, however, were not significant: size in €billions (based on NAV) (size), closing position of asset denominated in currency other than reporting currency as a share of total assets (closing position) (foreigncurr_ta), sum of Financial Services Fees_Euro + Other Professional Fees_Euro + Other Operating Expenses_Euro)/Total assets (expense_ta), sum of all increases and decreases of derivatives transactions. Both assets and liabilities are included (derivative_nav).

${ }^{11}$ The value associated with the highest decile of daily turnover relative to NAV is 17 percent. A total of 529 observations involving 143 funds are dropped. This cutoff occurs at the point where the positive skew of the distribution is maximally reduced. We also deleted the upper and lower 0.5 percentile of all the variables to exclude influential outliers.

${ }^{12}$ This ensures that the dummy variable coefficients can be interpreted without subtraction from an intercept term. If this adjustment is not made, the Stata
} 
Given that our dependent variables are serially correlated, we include a lagged dependent variable in our regression, and this leads naturally to estimation of a dynamic panel. We employ the dynamic panel methods pioneered by Holtz-Eakin, Newey, and Rosen (1988) and further developed by Arellano and Bond (1991), Arellano and Bover (1995), Blundell and Bond (1998), Baum, Schaffer, and Stillman (2003), Windmeijer (2005), and Bai and Ng (2010). Specifically, we use an Arellano-Bond/Arellano-Bover dynamic panel which is a difference generalized method of moments (DGMM) where the individual fund fixed effect is purged using orthogonal deviation and the lagged level variables are used to instrument the transformed equation 13 All individual fund characteristics and the lagged values of the dependent variable are considered endogenous and are instrumented with their second and third lags. QE variables and the foreign financial variables are considered strictly exogenous 14

The above model is applied to two different subsamples of investment funds based on whether or not they have held a significant fraction of their portfolio in the form of PSPP assets. Specifically, we denote funds as PSPP holders if they have, in any quarter of our sample, held at least 10 percent of their portfolio in PSPP assets bought by the ECB between March 2015 and June 2016. The second sample (non-PSPP holders ) includes funds that have never held PSPP assets 15 In our discussion of results we focus almost entirely on the case of PSPP holders, as they are the only potential sellers to the ECB. We also rely more on the results explaining net purchases rather than the proportional holdings. We do not generally

procedure includes an intercept, and this is awkward to interpret since it implicitly applies to all periods.

${ }^{13}$ As compared to Arellano and Bond (1991), the transformed equation in Arellano and Bover (1995) is obtained by subtracting the average of all available future observations instead of differencing. The model is particularly suitable for unbalanced panel, as it has the virtue of preserving the sample size.

${ }^{14}$ For the QE variables we also use the pass-through option in order to avoid their transformation and to guarantee that they are instrumented with their own value. For all regressions we use a robust two-step estimator where the standard covariance matrix is robust to panel-specific autocorrelation and heteroskedasticity and the standard error is correct using the Windmeijer finite sample methodology.

${ }^{15}$ The samples are identified using ISIN-level intervention data provided by the Financial Market Division of the Central Bank of Ireland. The use of those data guarantees no uncertainty in the identification of PSPP holders. 
find significant results for the case of proportional holdings (i.e., passive effects) of PSPP holders or for the rebalancing of the non-PSPP holders 16

Summary statistics for the dependent variables and the fund characteristics (including the "within" and "between" standard deviations) for the PSPP holders are provided in tables 1, 2, and 3. The results reveal that most of the variance is explained by cross-unit variation, while the within variation is limited. The only exception is for redemption and issuance, which display a substantial within variation.

Before discussing regression results, it is worth noting from descriptive statistics in table 3 that there is significant correlation between the proposed explanatory variables in equation (2). The pooled correlations shown in the top panel of table 3 reveal that turnover is highly correlated with leverage (0.63), foreign currency position (0.26), and issuance (0.21). These raw correlations are difficult to interpret - specifically, we do not know whether they reflect common time or cross-sectional variation.

\section{Data and Results}

\subsection{Data}

Our analysis focuses on the large investment fund industry domiciled and reporting in Ireland 17 The Central Bank of Ireland's Statistics Division collects quarterly balance sheet information and monthly investment fund information through investment fund returns. These data provide a comprehensive overview of all funds' quarterly accounts characteristics, gross buy-and-sell transactions, and positions vis-á-vis residents and non-residents by reporting currency. Accounting information includes - amongst other items - the security-by-security information on holdings of equities, debt securities, and derivatives; profits and losses per period on an accruals basis; interest, dividends, rents, and other income. Our data set

\footnotetext{
${ }^{16}$ In the non-PSPP sample we also include dummy variables that capture the type of fund (bond, equity, hedge, money market fund, mixed, other, or real estate).

${ }^{17}$ The total asset value of the sector in 2016:Q3 is about $€ 2$ trillion.
} 


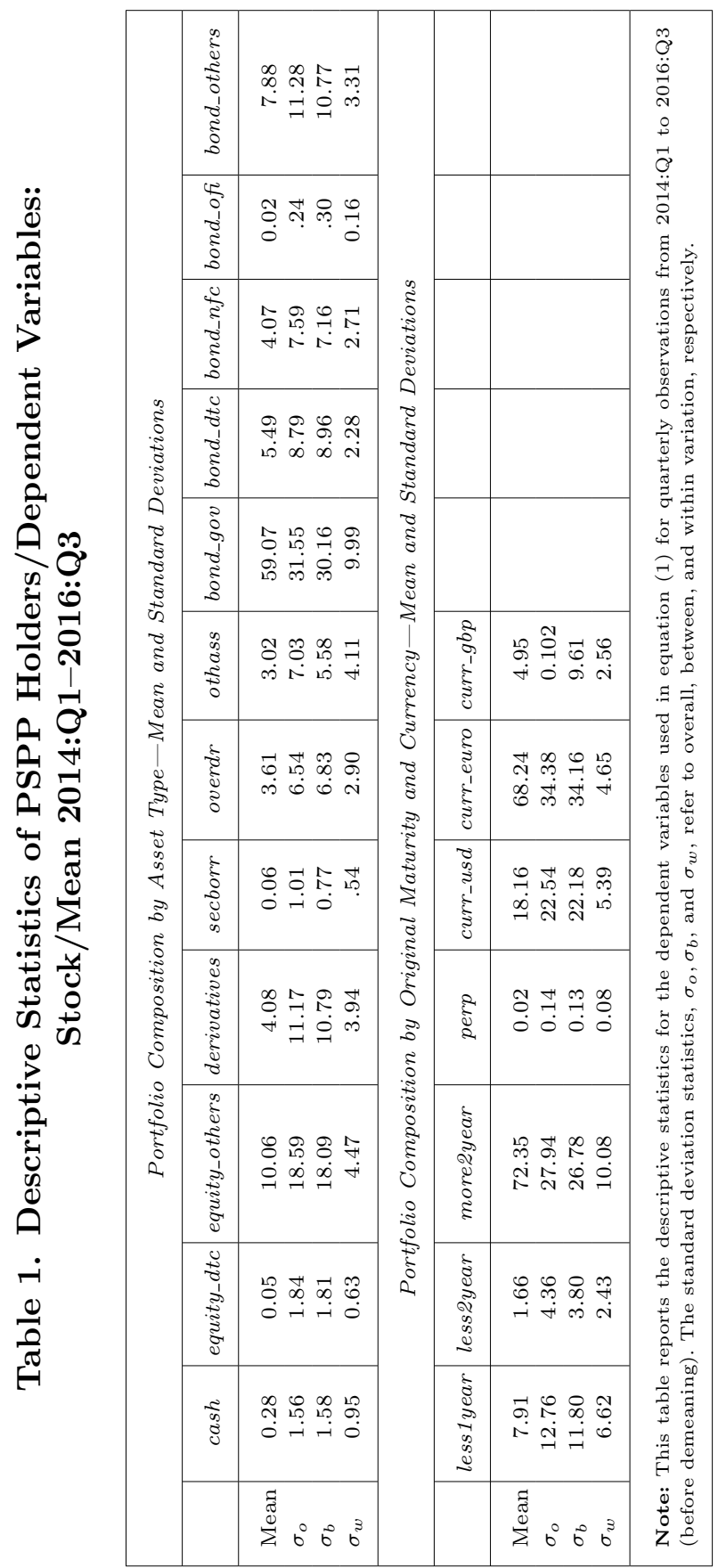




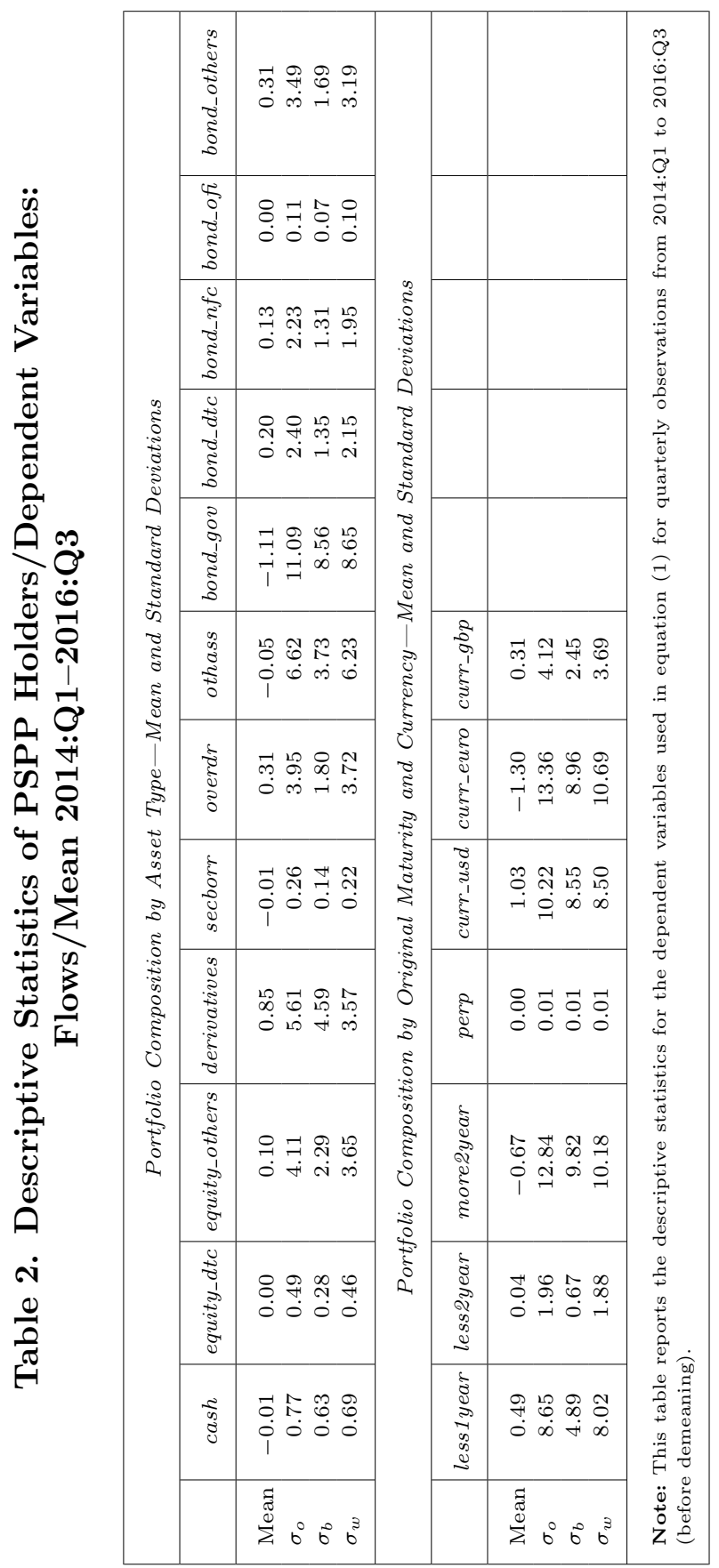




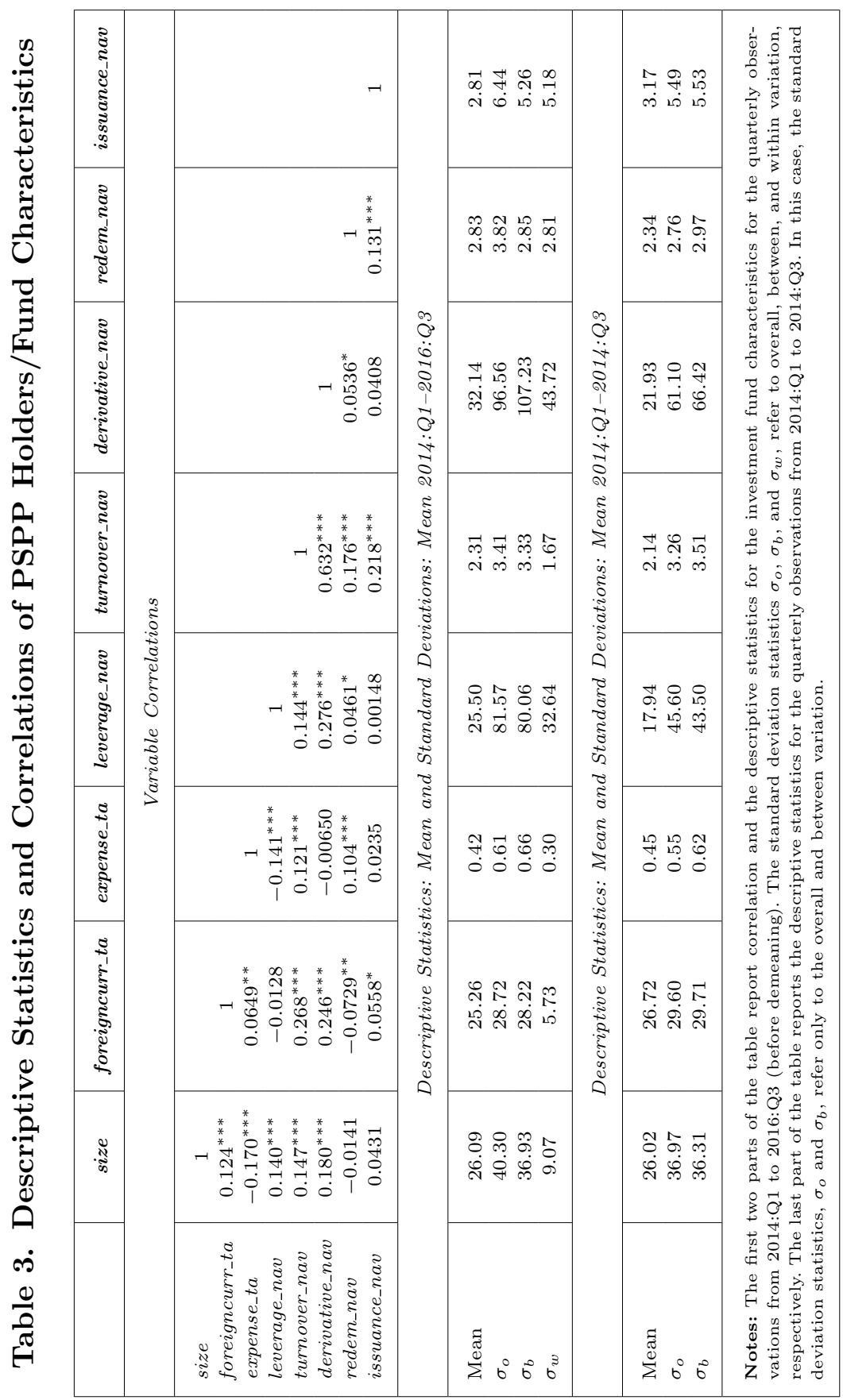


spans the quarters from 2014:Q1 to 2016:Q3 and includes all investment funds categorized as equity, bond, mixed, hedge, real estate, money market, and others. As we mentioned previously, we structure the analysis by two subsamples depending on whether funds have a substantial holding of PSPP assets. We obtained all event-byevent PSPP intervention data by ISIN identifiers from the Markets Division of the Irish Central Bank.

Table 4 provides a first overview of the two samples. This reveals that PSPP asset holders are mainly dominated by bond and mixed funds, while the non-PSPP asset holders are dominated by equity funds 18 Figure 2 provides a deeper look into the portfolio of PSPP holders and suggests that most of the funds hold a very small percentage of PSPP assets (right axis). Also, combining the share of PSPP holdings with the interquartile range of their value (left axis), the graph suggests that large PSPP holders are also large funds 19

Figure 3 plots the average end-of-quarter proportional portfolio compositions of the PSPP asset-holding funds according to asset type/issuer, maturity, and currency (as defined above). In the case of the holdings by asset type, the graphs include only the main types (i.e., cases where, on average, the asset type represents more than 4 percent of the total assets held by the funds) 20 We see that, on average, portfolios of PSPP asset-holding funds are heavily concentrated on government bonds denominated in euros with maturity longer than two years. The time profile of proportional holdings exhibits limited movement. In fact, the proportional holdings of government bonds has clearly increased since the start of the ECB's asset program. This suggests that funds have persistent preferences, but it does not necessarily reflect the true impact of the EAPP. The increase in the share of assets allocated to government bonds could merely be the consequence of revaluation effects combined with redemptions.

\footnotetext{
${ }^{18}$ The total asset value of the PSPP holders in 2016:Q3 is about $€ 340$ billion, while for non-PSPP holders it is about $€ 1.6$ trillion.

${ }^{19}$ For example, size can vary a lot-from about 80 million to 1 billion for the bar between 0.6 and 0.7 - which are funds that held between 60 and 70 percent of their portfolio in PSPP assets.

${ }^{20}$ Figures are the values before demeaning and after removing funds with turnover relative to NAV $>17$ percent.
} 


\begin{tabular}{|c|c|c|c|c|c|}
\hline 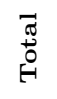 & \multirow{13}{*}{ 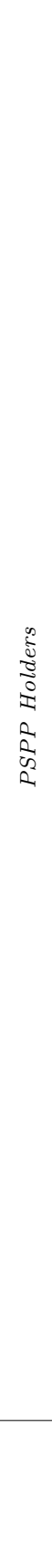 } & 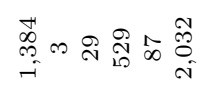 & \multirow{13}{*}{ 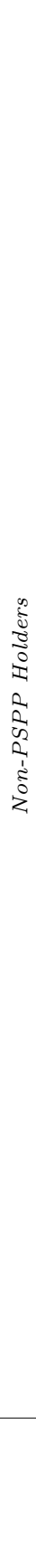 } & 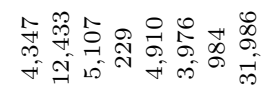 & \\
\hline $\begin{array}{l}\text { ơ } \\
\ddot{\theta} \\
\stackrel{\sim}{0}\end{array}$ & & 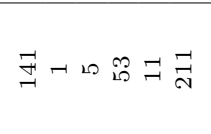 & & 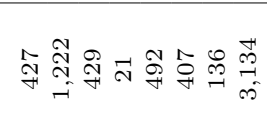 & \\
\hline $\begin{array}{l}\text { Õ } \\
\ddot{0} \\
-1 \\
\text { ○े }\end{array}$ & & 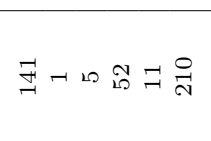 & & 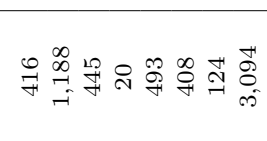 & \\
\hline 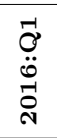 & & 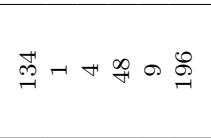 & & 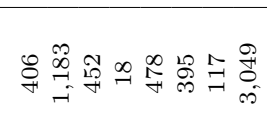 & \\
\hline $\begin{array}{l}\overrightarrow{0} \\
\ddot{0} \\
\stackrel{1}{0} \\
\stackrel{\sim}{0}\end{array}$ & & 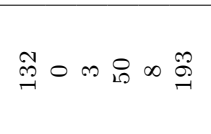 & & 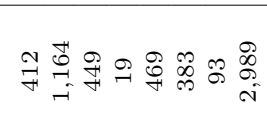 & \\
\hline 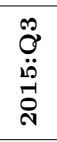 & & 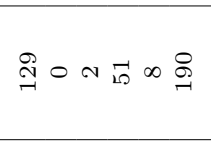 & & 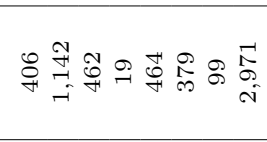 & $b_{0}^{\circ}$ \\
\hline $\begin{array}{l}\text { ơ } \\
\text { iñ } \\
\text { ஸे }\end{array}$ & & 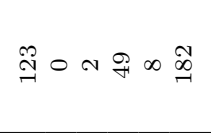 & & 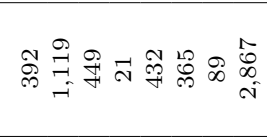 & 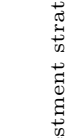 \\
\hline 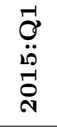 & & $\vec{I} \circ \infty \forall \infty \stackrel{\mathscr{N}}{=}$ & & 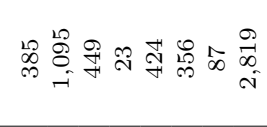 & 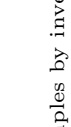 \\
\hline 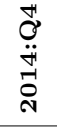 & & 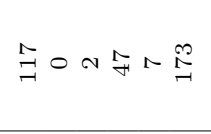 & & 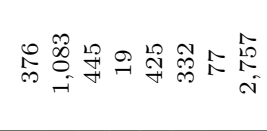 & 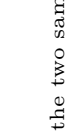 \\
\hline 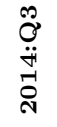 & & $\stackrel{g}{\exists} 0-$ 年0 胥 & & 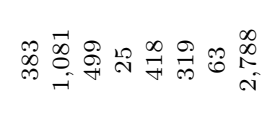 & 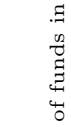 \\
\hline 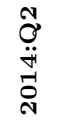 & & 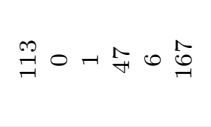 & & 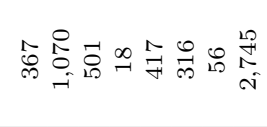 & 音 \\
\hline $\begin{array}{l}\tilde{\sigma} \\
\ddot{H} \\
\stackrel{\sim}{\pi}\end{array}$ & & 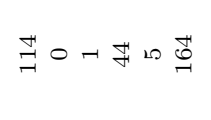 & & 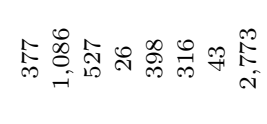 & 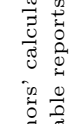 \\
\hline & & 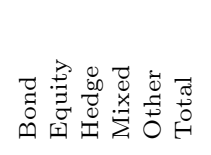 & & 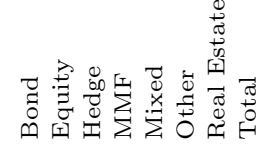 & 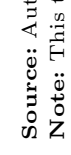 \\
\hline
\end{tabular}


Figure 2. Distribution of Share of PSPP Assets Held by Each Fund in Percent (right axis) and Interquartile Range of the Value of the PSPP Assets in the Portfolio of Each

Fund (left axis)

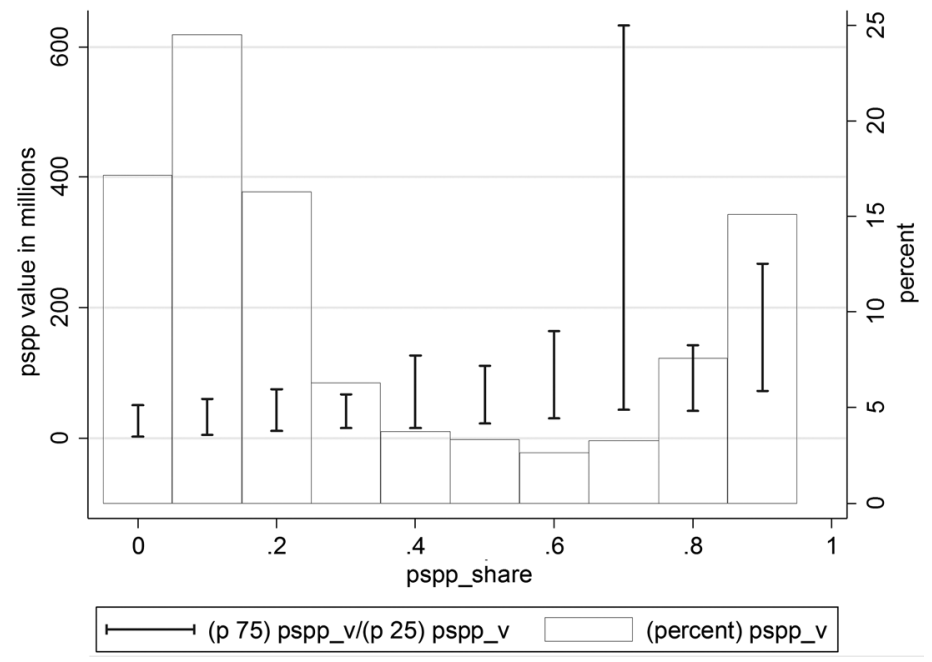

Figure 3. PSPP Holders: Portfolio Composition/Stock

A. Asset Type

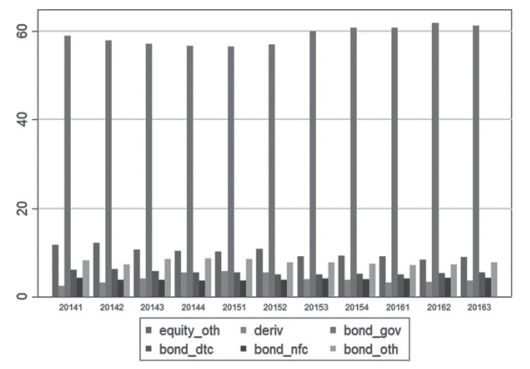

B. Maturity

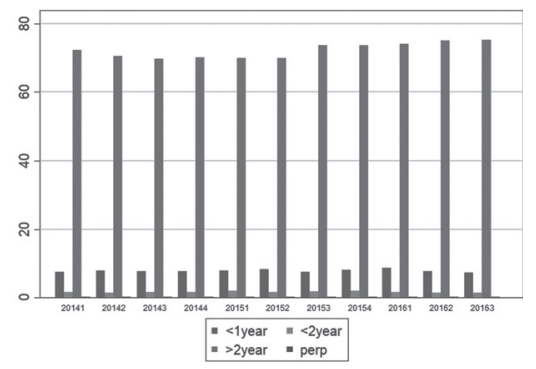

C. Currency

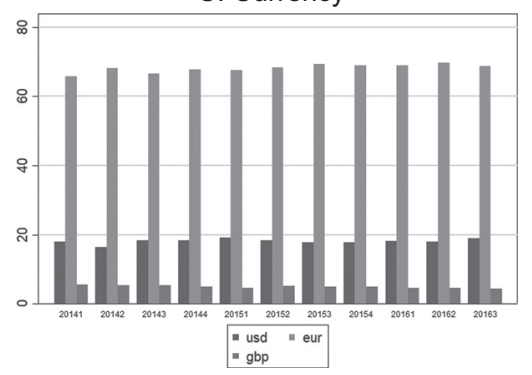




\section{Figure 4. PSPP Holders: Portfolio Composition/Net Purchases}
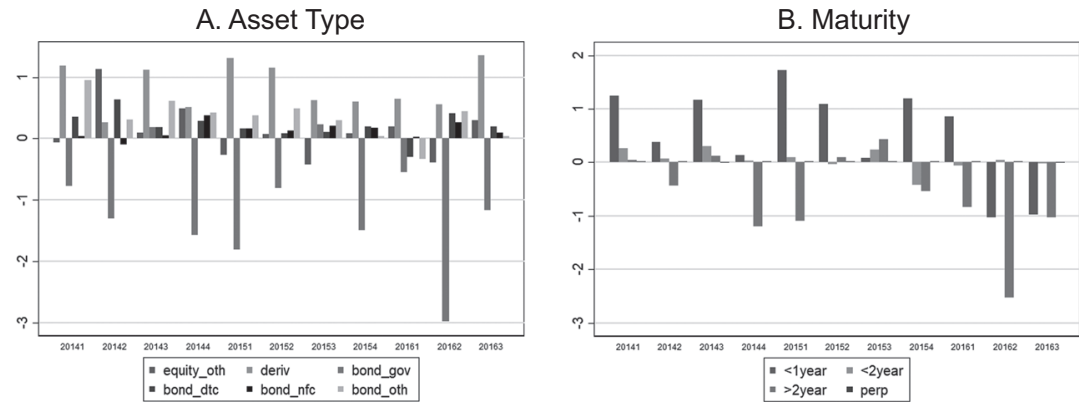

C. Currency

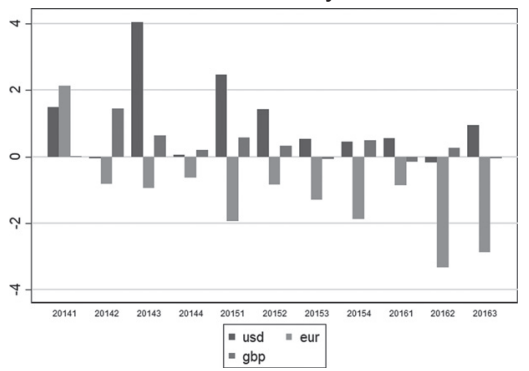

More reliable insights about rebalancing can be added from an examination of transactions for the same asset classes. Figure 4 shows net purchases, and this produces quite a different picture from that of the proportional holdings. On a net basis, funds have clearly sold euro-denominated government bonds (particularly those with maturity longer than two years). They also seem to have moved towards other types of bonds and to derivatives 21 This graphical analysis seems to support the presence of a portfolio rebalancing channel. However, it is important to assess whether this behavior could be due to normal rebalancing prompted by non-QE-related macroeconomic developments. We now consider the results of a

\footnotetext{
${ }^{21}$ Results for non-PSPP holders are reported in figure 5 and figure 6. Overall, the non-PSPP funds seem to hold mainly equities denominated in U.S. dollars. Their portfolios are spread across all maturities. Also, net purchases do not suggest a clear rebalancing pattern.
} 
Figure 5. Non-PSPP Holders: Portfolio Composition/Stock

A. Asset Type

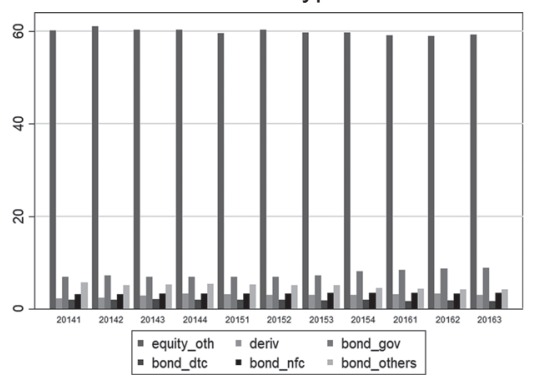

B. Maturity

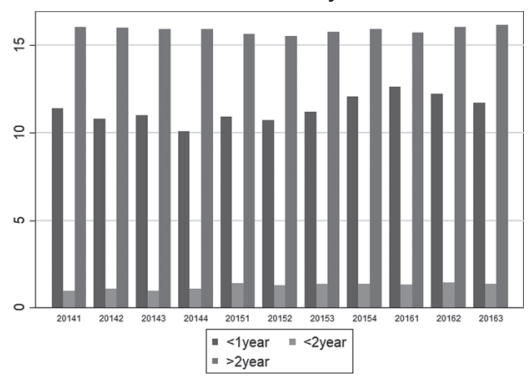

C. Currency

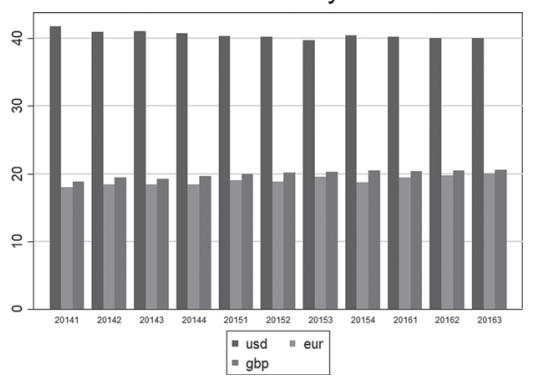

Figure 6. Non-PSPP Holders: Portfolio Composition/Net Purchases

A. Asset Type

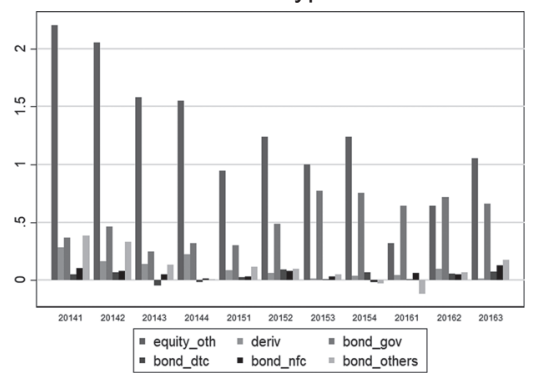

B. Maturity

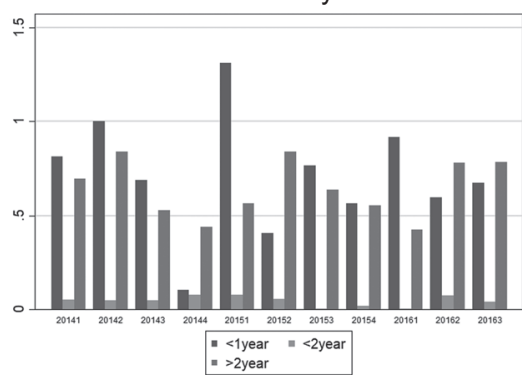

C. Currency

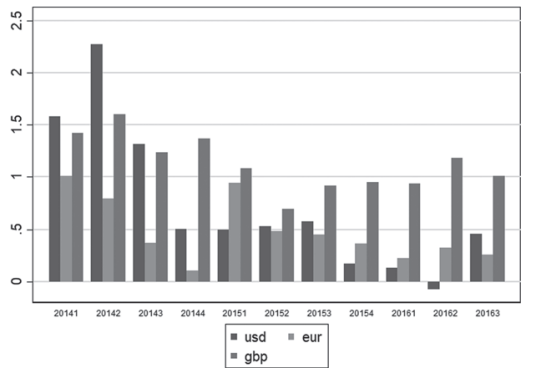


panel regression analysis that quantifies the rebalancing sensitivity to asset purchases for the different phases of the program while controlling for fund characteristics, macroeconomic developments, and fund fixed effects.

\subsection{Results}

Table 5 provides results for the dynamic panel regression in equation (1) explaining net purchases of the six largest asset classes in the portfolios of funds defined as significant holders of PSPP assets. In this first regression we exclude fund characteristics in the control set. We use the Arellano-Bover forward orthogonalization approach to purge fixed effects. In general, the results have intuitive appeal and their interpretation coincides with our expectations. Overall, there is only significant evidence of rebalancing during the second phase of the purchase program and only two assets in which significant QE rebalancing effects can be identified. The coefficients on the second-phase QE dummies $\left(Q E \_s e c o n d\right)$ indicate that net purchases of government bonds are more negative than usual, and net purchases of bonds issued by deposit-taking corporations are greater than usual, when the program was scaled up. The significant negative flows out of government bonds in the second phase of the program probably reflects both the increased intensity of purchases and an increased willingness to divest of APP assets at the first sign of improving economic conditions (which could signal an earlier timing of tapering than originally expected). We find no significant rebalancing effects during the anticipation period and no significant rebalancing flows in any QE period towards equities or derivatives. It is worth noting that equities and derivatives represent only a very small proportion of the portfolio of the funds (see table 1).

While this first regression provides limited but broadly supportive evidence for rebalancing, it should be noted that, despite the presence of a lagged dependent variable, the regression residual remains significantly autocorrelated in two cases (there is clear evidence of $\operatorname{AR}(2)$ in the differenced error, implying $\operatorname{AR}(1)$ in levels for the case of bonds issued by governments and by deposit-taking institutions). Furthermore, the tests for validity of the GMM instruments indicate weakly specified models in the cases of bonds issued 


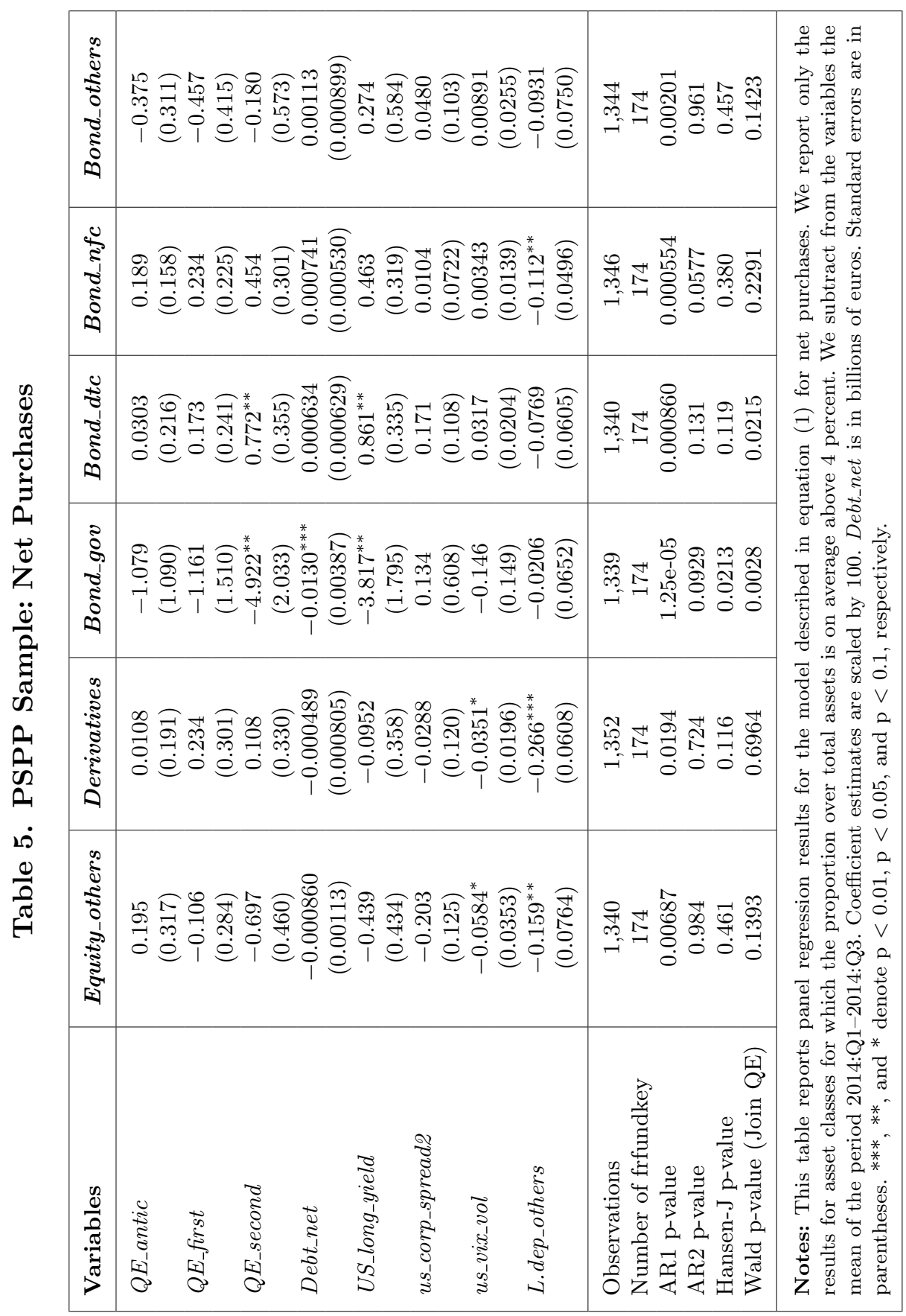


by governments and by NFCs. These issues are ameliorated to a significant extent in the more general specification now discussed.

Table 6 provides regression results for equation (2) where we include fund issuance, redemption, leverage, and turnover characteristics (both on their own and interacted with QE dummies) to explicitly allow heterogeneity in portfolio rebalancing behavior across funds. In comparison with the first set of regression results, we observe a similarly significant (but now larger) increase in the purchase of the bonds issued by deposit-taking institutions regardless of the fund characteristics (i.e., a significant positive coefficient on the $Q E \_s e c o n d$ dummy in the Bond $d_{d t c}$ column). The net purchase of bonds of deposit-taking institutions is also large and statistically significant for the second QE period among the funds that are relatively more engaged in the issuance of new fund units (i.e., a significant positive coefficient on the Second_iss dummy).

The significant negative effect found in our first regression in the case of net purchases of government bonds on the non-interacted $Q E \_s e c o n d$ dummy becomes insignificant in the more general specification. However, we now see that the coefficient on redemption on its own, redem_nav, is negative and significant and there are two significantly negative coefficients on the interactive QE dummies First $_{r d m}$ and Second ${ }_{r d m}$ ), indicating net sales of government bonds by funds that experienced relatively more redemptions of fund units generally and specifically during the QE-active periods. This is consistent with a coincidence in the rebalancing behavior of fund investors away from funds focused on holding government bonds and rebalancing away from government bonds by the funds themselves. The coefficient on issuance on its own is significantly positive, but there is no significance for the interaction of issuance with QE dummies.

There is significant support for the rebalancing channel due to movement into bonds issued by those classified as "other" $\left(\right.$ Bond $\left._{\text {other }}\right)$. Here we observe significantly more net purchases during each of the QE-active periods by funds experiencing relatively higher redemptions as well as those experiencing relatively more issuance of their own units (i.e., significance of coefficients on

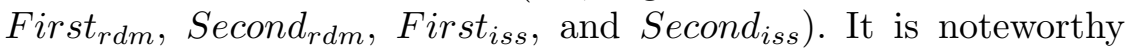
that there was little significant evidence of rebalancing towards equities (except for the case of funds with relatively more leverage) or 


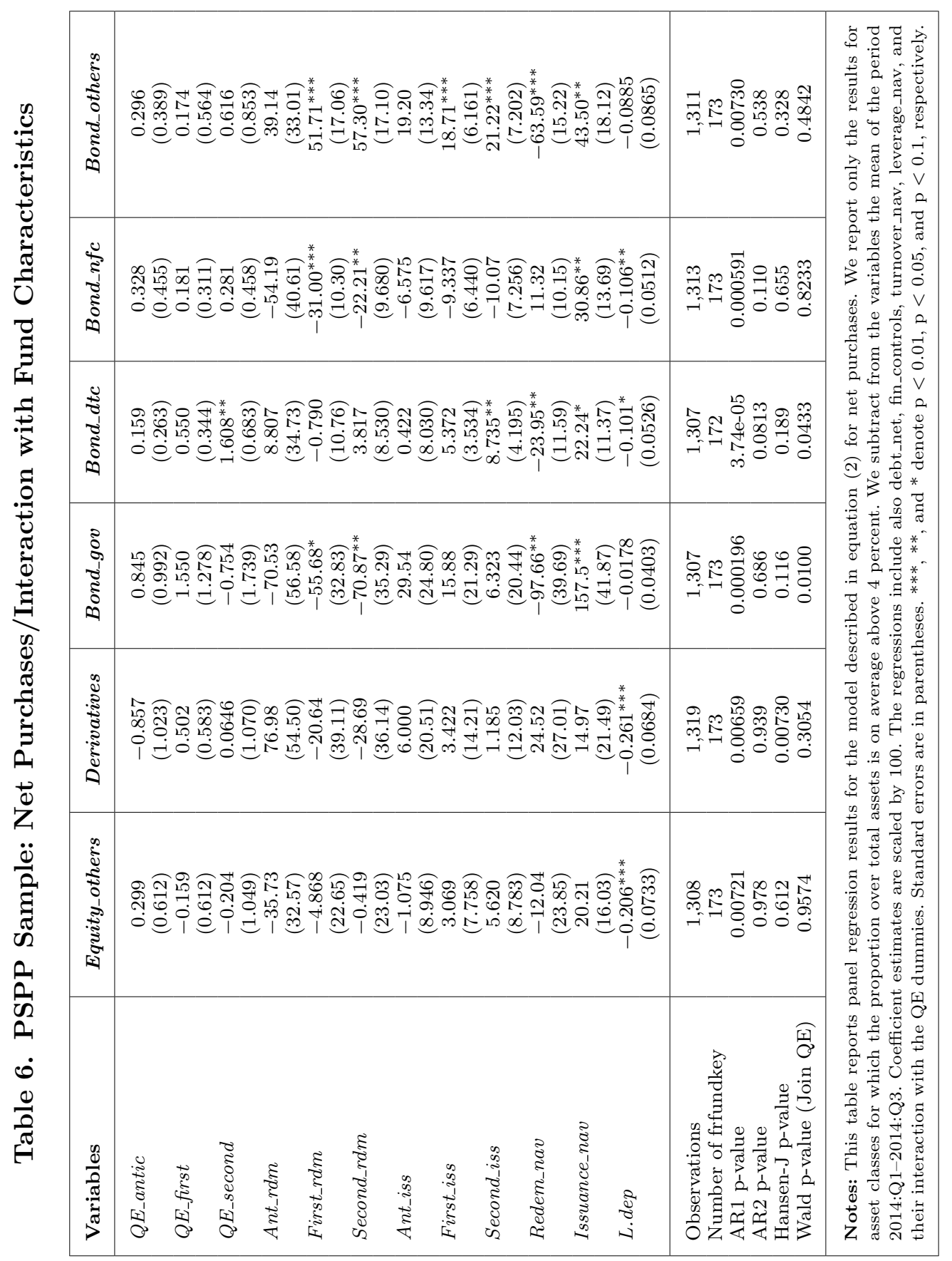


derivatives, even though these assets are significant (if small) elements of the PSPP holders' portfolios. Overall, the results for this more flexible regression specification are relatively supportive of a rebalancing channel at work. However, the issuance currency of the assets substituted for PSPP assets in portfolios has yet to be considered, so the exact transmission mechanism of the purchases is still not entirely clear (we return to this below).

Contrary to our prior expectations, there is evidence of a withdrawal from bonds issued by non-financial corporations $\left(\right.$ Bond $\left._{n f c}\right)$ in both QE-active periods by funds with relatively high redemptions. Thus, unlike the findings of studies of rebalancing behavior during U.S., U.K., and Japanese QE programs, NFCs do not seem to benefit from portfolio rebalancing in the euro-area case (investment is instead directed towards bank bonds and bonds of issuers classified as "other").

The results just discussed hint at a rebalancing channel through redemptions and issues in combination with portfolio rebalancing at the fund level. We also found some correspondence in the level of leverage and QE effects. To assess these indirect channels, we examine how redemptions, issues, leverage, and turnover for PSPPholding funds was affected by EAPP. Table 7 provides results for regressions with a similar structure to that of equations (1) but with redemption, issuance, leverage, and turnover (all relative to NAV) as the dependent variables. We see that redemptions rose more significantly than issuances for the PSPP-holding funds, and these effects are rising in magnitude over the course of the asset purchase program and its anticipation. The use of leverage seems to have been unaffected by the EAPP, and turnover only rose significantly in the second QE-active period. Overall, the redemption, issuance, and activity evidence is consistent with a flight of investment away from PSPP-holding funds.

The non-PSPP holders were not directly affected by the relatively high level of purchases of PSPP assets by the ECB because, by definition, they were not holding PSPP assets. However, the standard rebalancing channel is expected to act indirectly through the higher pricing (and lower yield) of assets that are close substitutes for the assets purchased. To assess whether there is any evidence for these indirect effects, we run the same regressions as above for various fund categories within the sample of funds that never held 


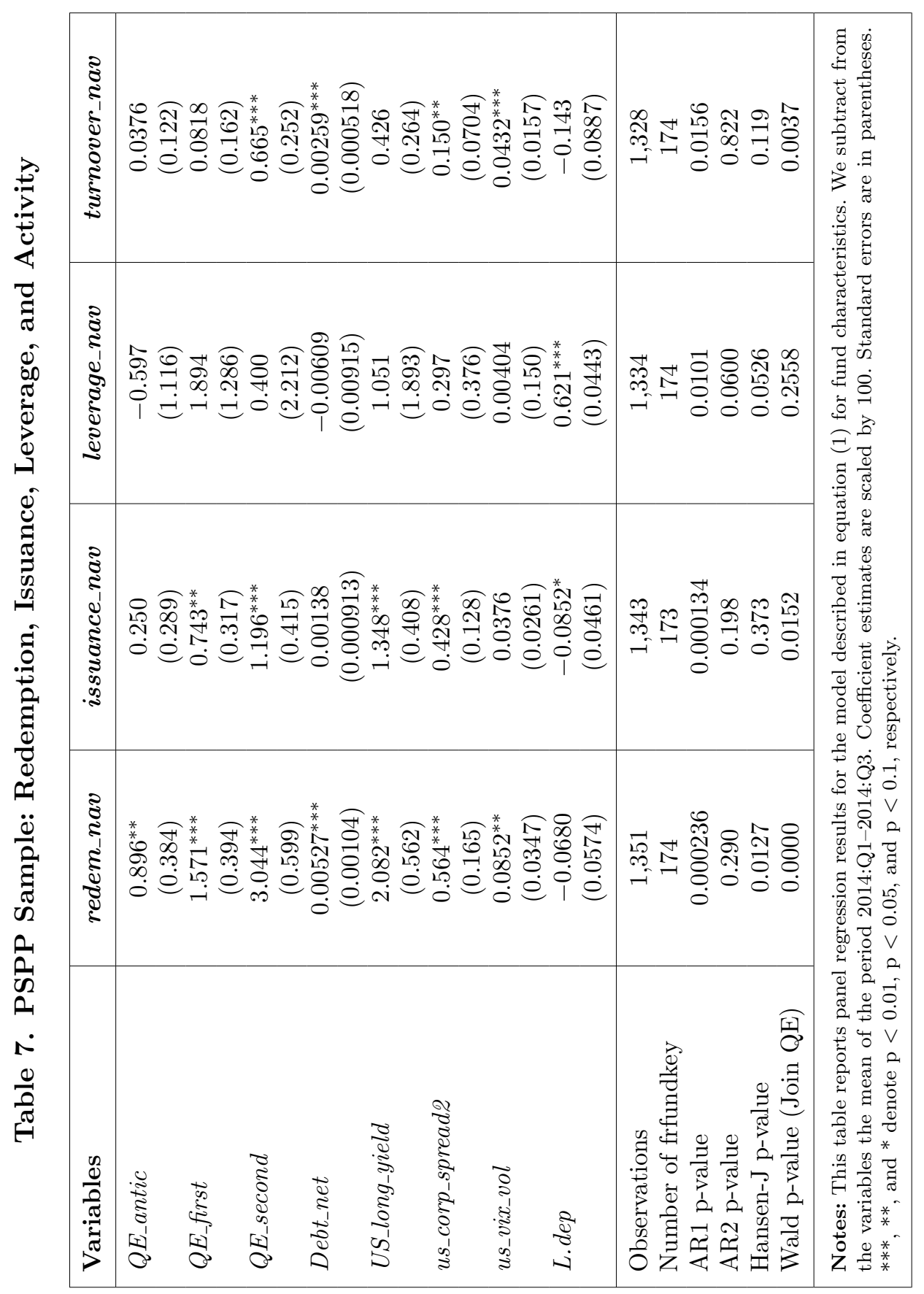


PSPP assets during our sample. Regression results pertaining to non-PSPP-holding funds categorized as bond, mixed, and "other" are displayed in tables 8,9 , and 10 , respectively. In this specification we exclude interactions between fund characteristics and QE dummies (again we focus on the regression explaining net purchases rather than the value of holdings).

In the case of non-PSPP-holding bond funds, table 8, the first result that confirms a rebalancing channel is the significant coefficient on the $Q E_{-}$second dummy in the case of Bondsgov. This shows that there were significantly higher net purchases of government bonds by non-PSPP-holding funds in the second phase of the EAPP (recall that these are funds that never held PSPP assets and it therefore implies a rebalancing to government bonds that were not eligible for purchase under the purchase program - either non-EA government bonds or those with non-eligible maturities). The only other significant effect was the selling of bonds issued by deposit-taking corporations in the QE anticipation period. This runs contrary to the presumed rebalancing channel.

Table 9 shows the analogous results for the mixed funds in the non-PSPP sample. In this case we find evidence of rebalancing during the anticipation period away from government-issued bonds (these could be bonds that are close substitutes for those anticipated to be purchased under EAPP) towards bonds issued by the NFCs in both the anticipation and first QE periods. The case of funds classified as "others" is contained in table 10, and here we see that there is a significant move away from equities and derivatives towards the net purchases of bonds issued by NFCs in the second QE period and towards bonds issued by unclassified issuers in both QE periods.

Once again, there is a possibility that investors are rebalancing across funds of different types. To assess this, we again run regressions explaining the redemption and issuance behavior of the non-PSPP-holding funds. Table 11 concerns redemption, issuance, leverage, and turnover for the non-PSPP bond funds. It might be expected that fund selection by investors would be visible through its effects on issuance and redemptions of units. In fact we see no evidence of increased redemptions. In support of movement into nonPSPP investment funds, we see strong evidence of increased issuance in the second QE period. Overall, this probably reflects an increase in investment in the non-PSPP fund sector specializing in bonds 


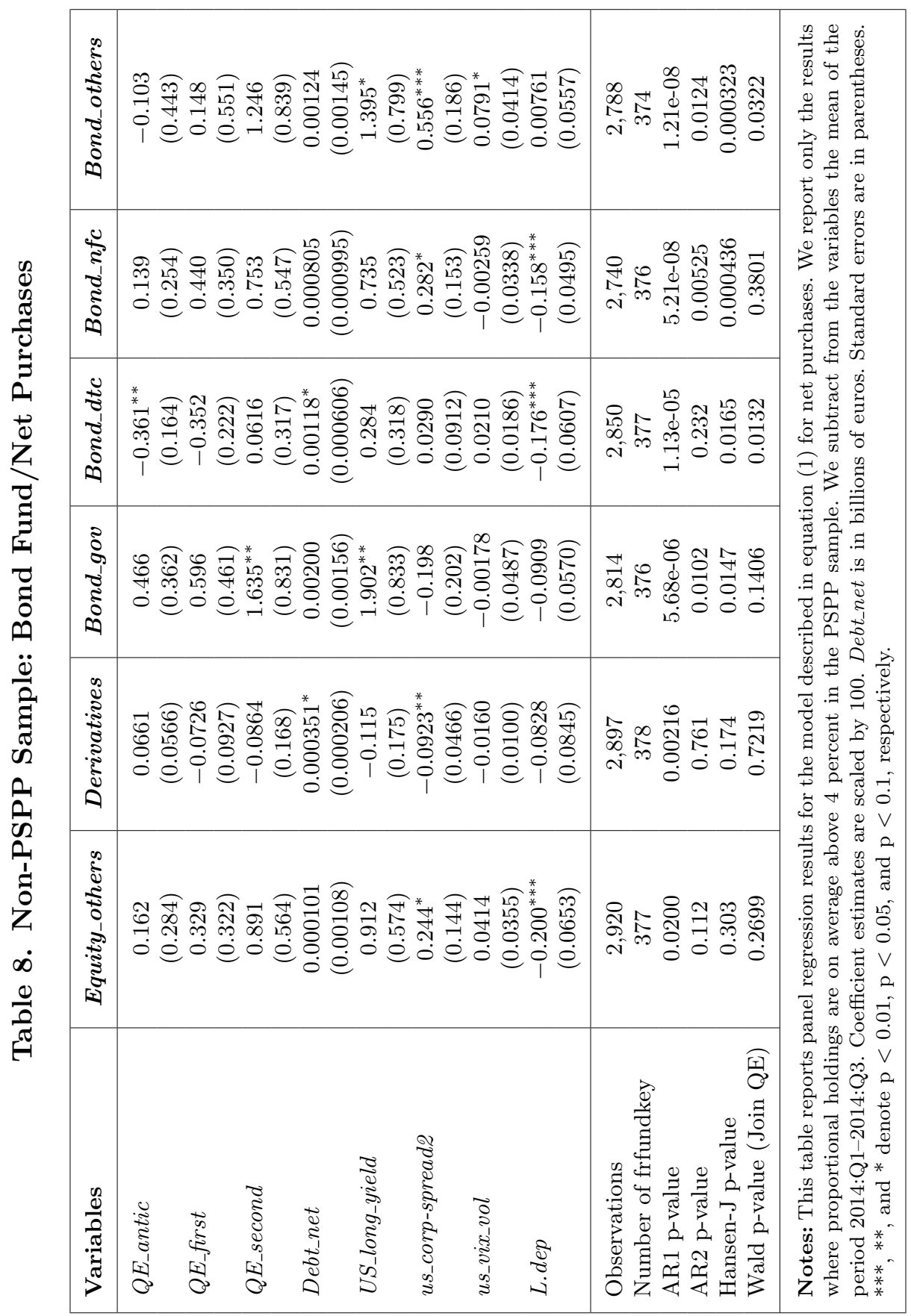




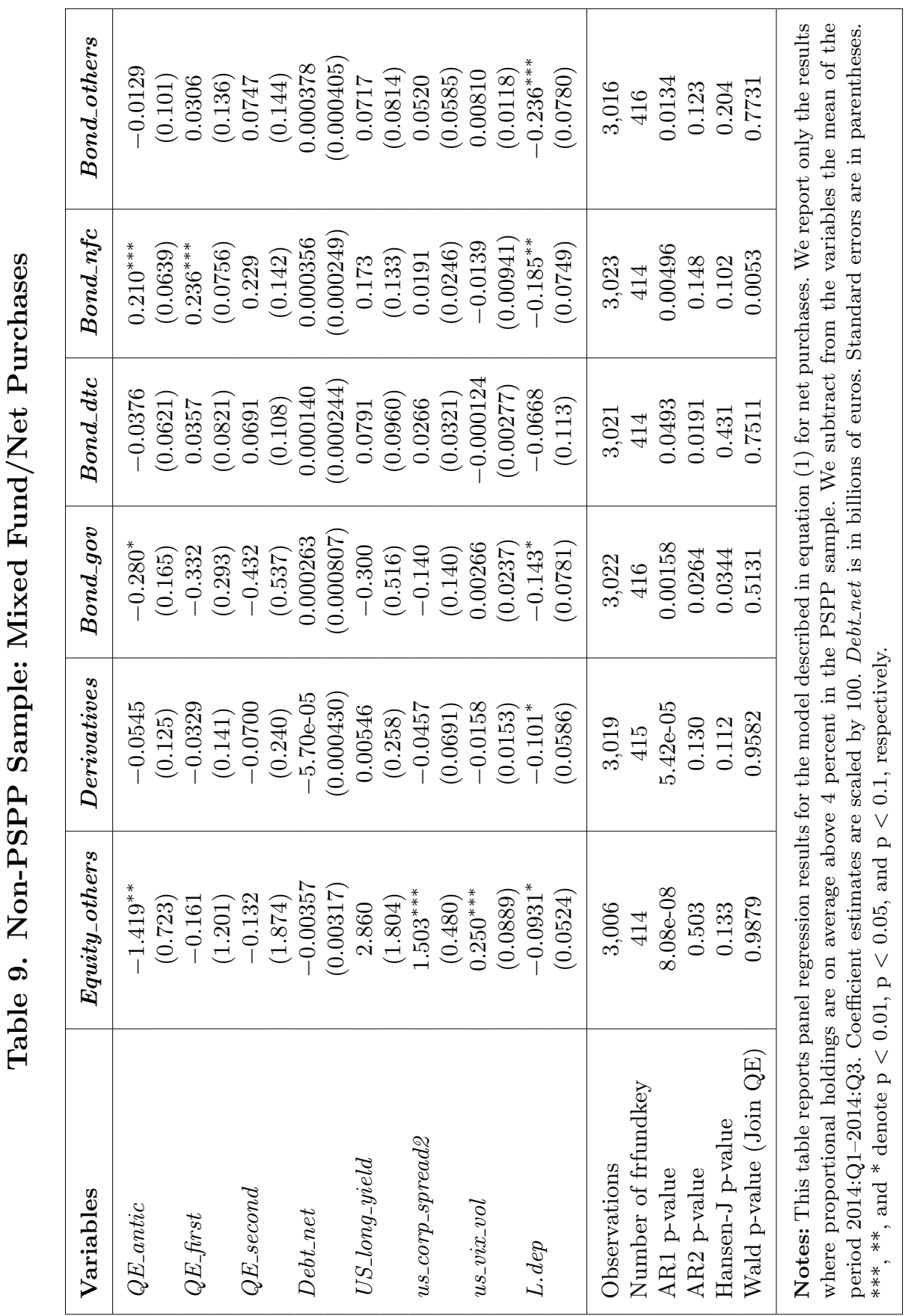




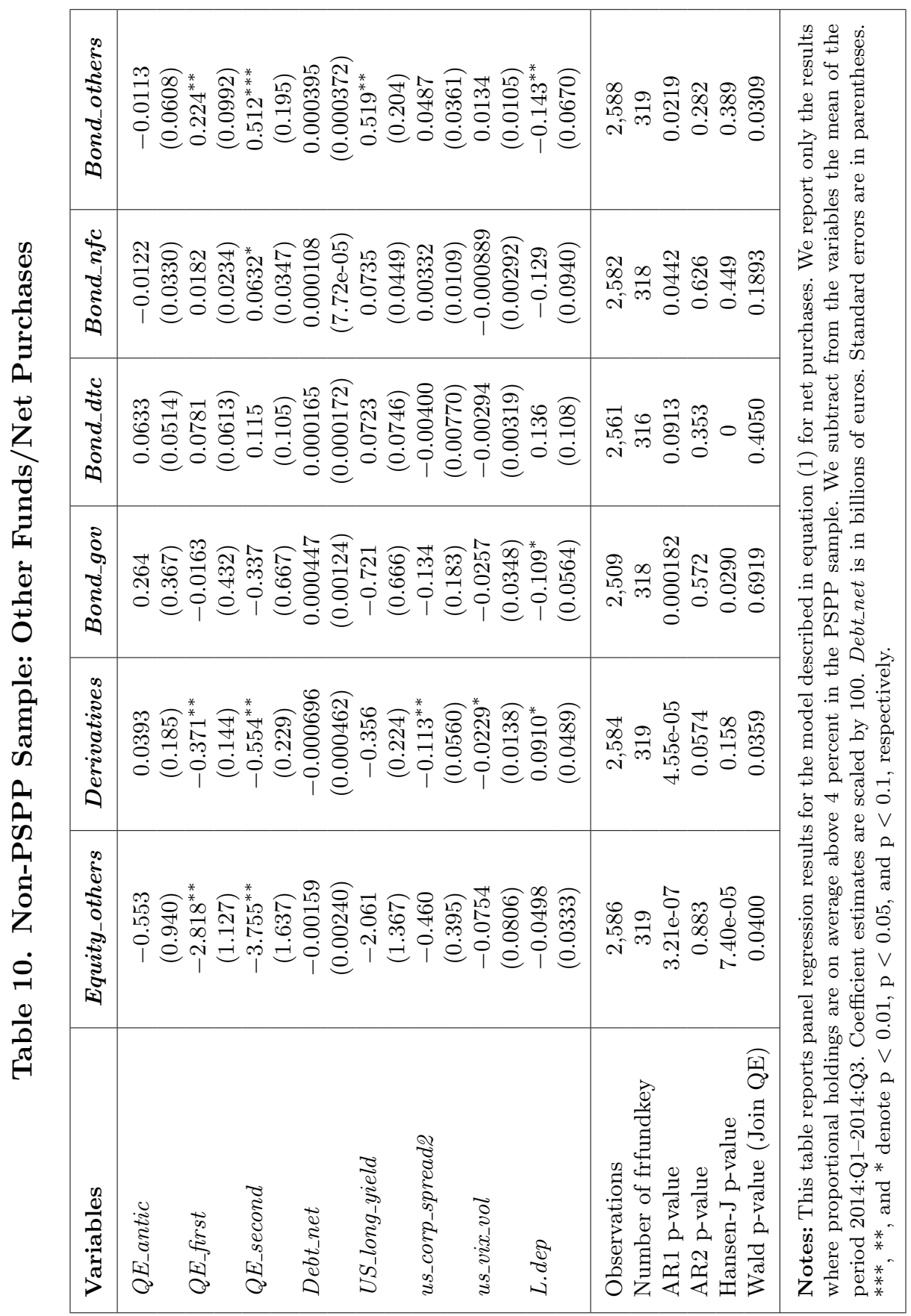




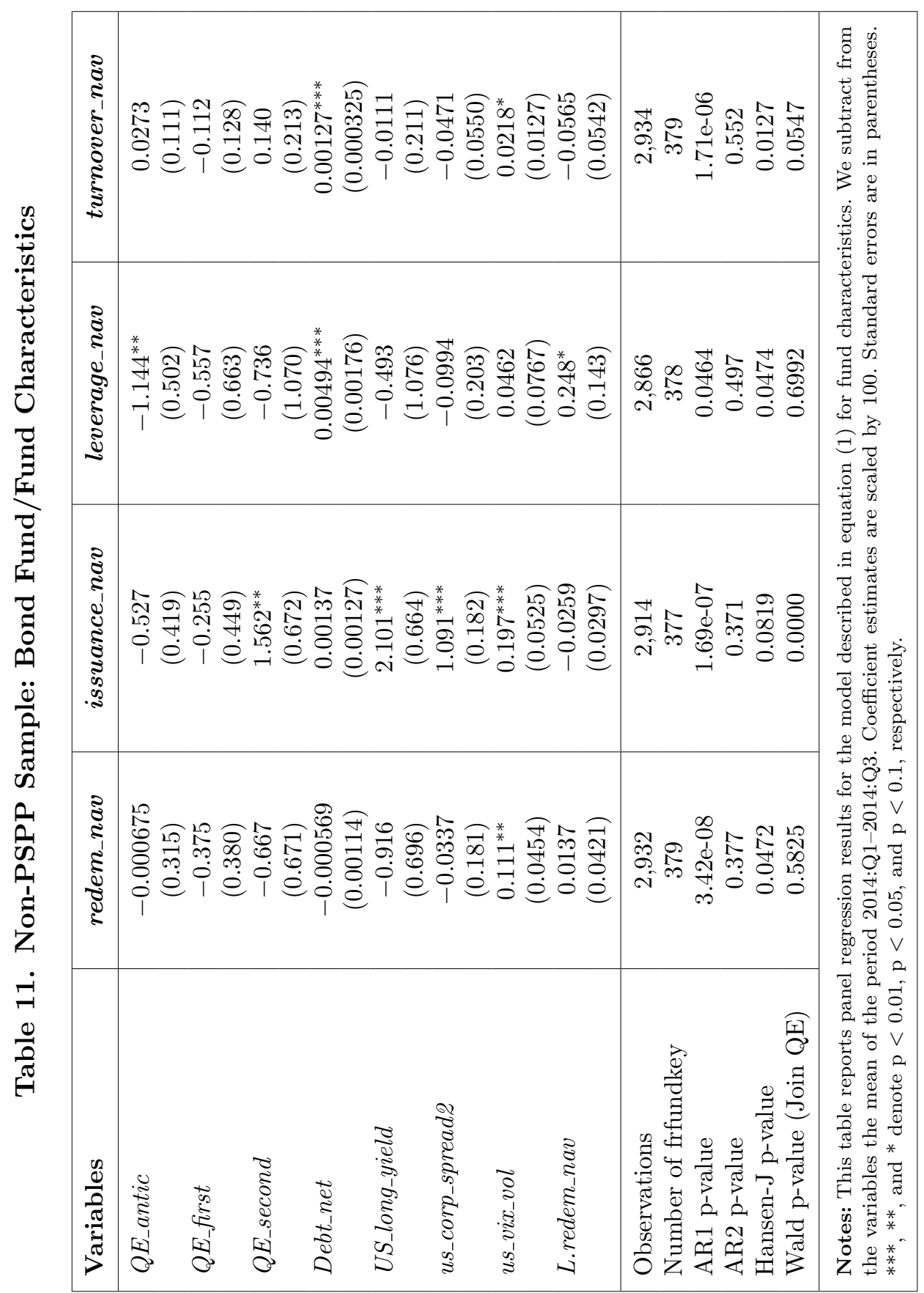


that can give investors similar exposure to what they would usually obtain from investment in units of PSPP-holding funds.

There is also a significant increase in issuance in both the first and second QE periods for mixed funds (table 12), combined with a distinct absence of any evidence for increased redemptions. So this category of non-PSPP holders also experienced net new investment. For "other" funds we find no evidence of redemption associated with QE but also no net issuance (table 13). Overall, there is substantial evidence that investors have moved their investments away from PSPP-holding funds towards non-PSPP-holding funds, and this confirms an investor-mediated rebalancing channel. This is also subject to a caveat, to which we now return, that such funds could be redirecting the new investment to non-EA assets.

\subsubsection{Rebalancing: Euro Area and the Rest of the World (RoW)}

The results so far concern the rebalancing of portfolios by asset type. Figure 7, panels A-D, shows four different views of net purchases according to the region of issuance of the assets concerned. Figure 7A shows, for the case of PSPP-holding funds, the EA/RoW breakdown of the two asset categories where significant parameters on net purchases were found (see table 5, specifically the columns relating to government bonds and bonds issued by deposit-taking corporations). In all eleven quarters shown there is strong evidence of net selling of EA government bonds. However, in nine out of eleven of the quarters we also observe net purchases of government bonds that are issued outside the EA. The situation concerning net purchases of bonds issued by deposit-taking corporations suggests that this activity was mostly in favor of those issued outside the EA.

Figure 7B presents the EA/RoW breakdown of the net purchases of government bonds by non-PSPP holders (these were also found to be statistically significant before being categorized as EA or RoW). The graphical breakdown clearly indicates that the majority of the rebalancing by non-PSPP holders was towards government bonds issued outside the EA. Likewise, figures 7C and 7D show that a large proportion of the "mixed" and "other" non-PSPP funds also exhibit rebalancing towards RoW assets. The associated regressions (not shown) support this finding once fund characteristics are interacted 


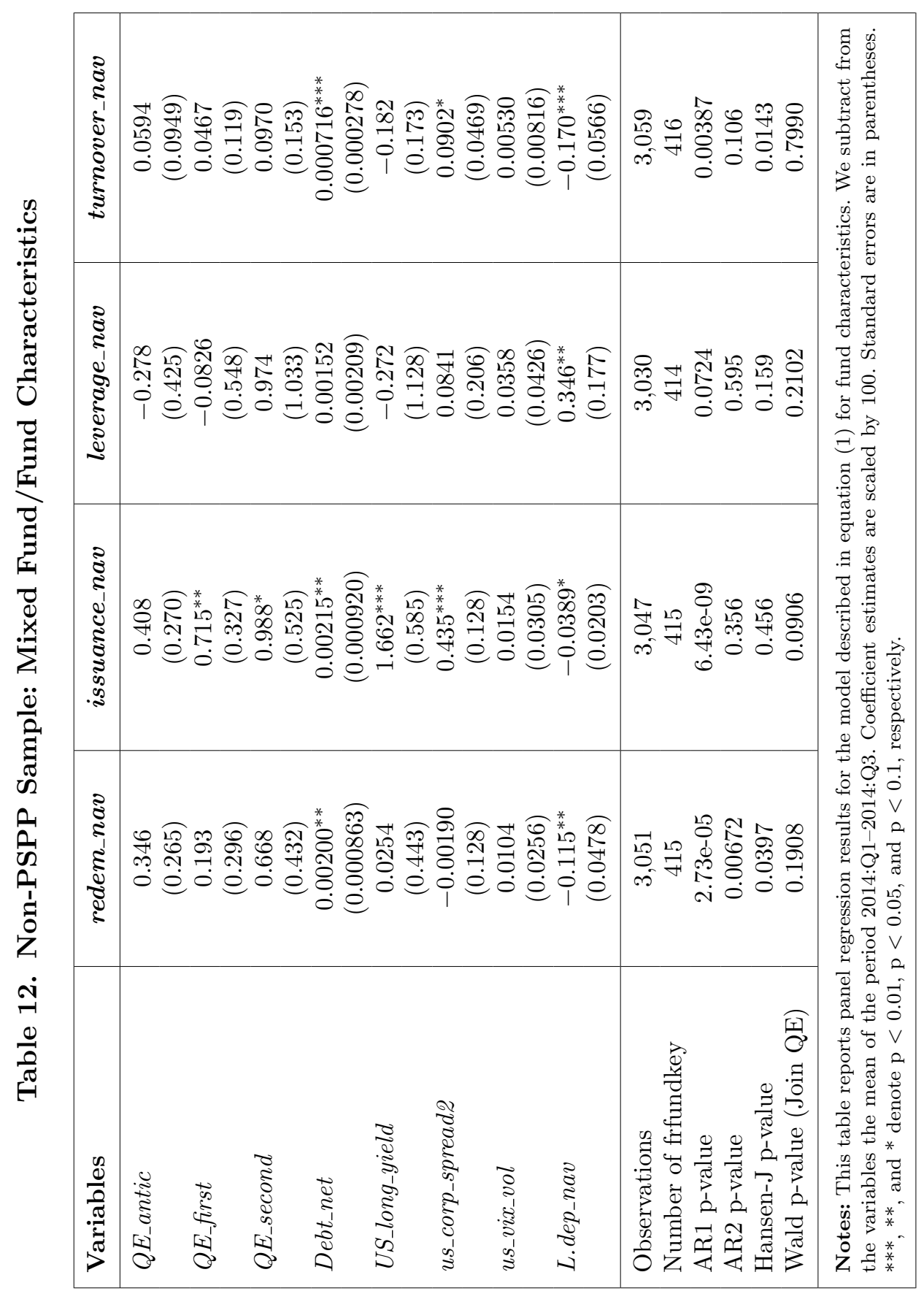




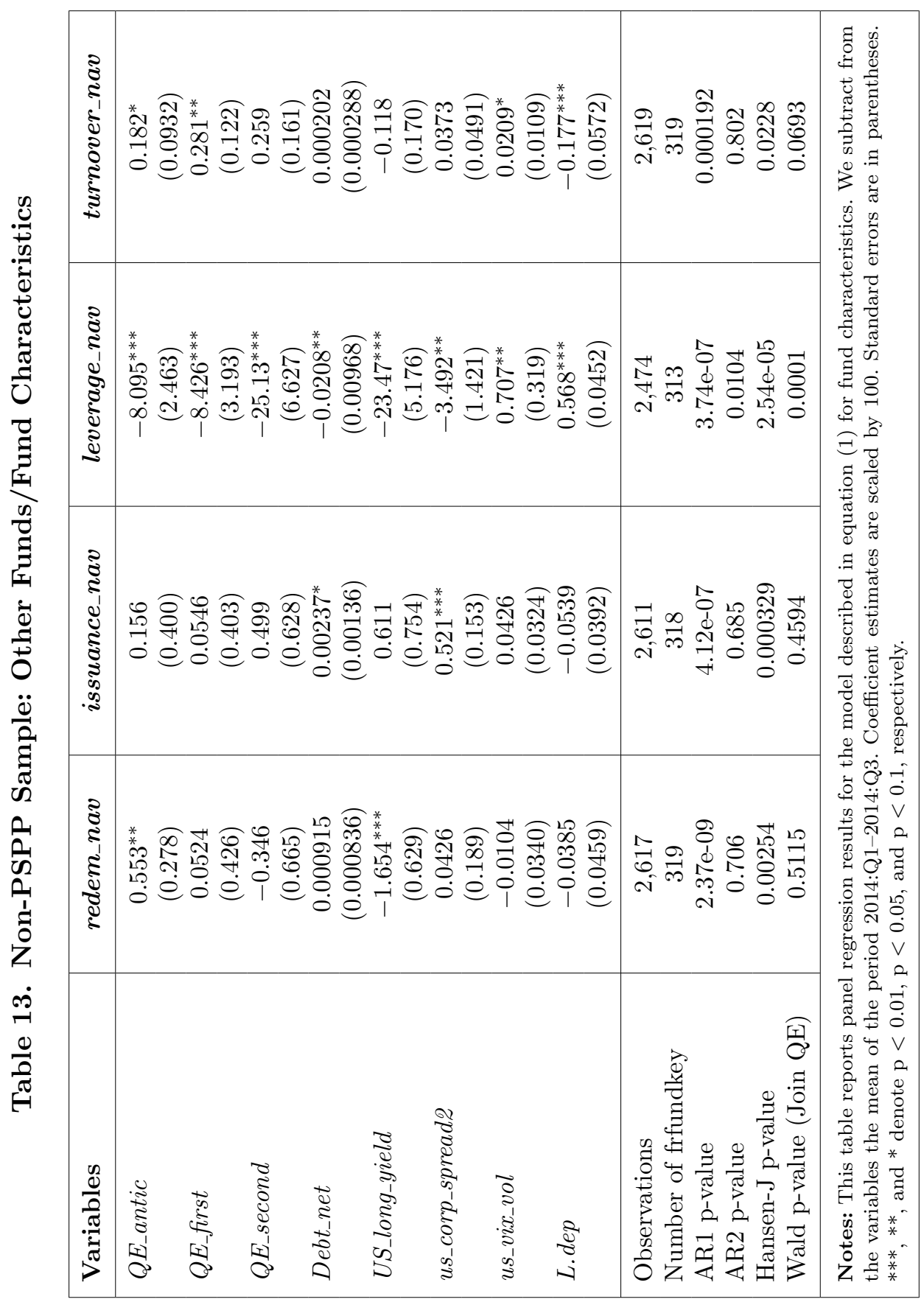


Figure 7. Asset Type and Area of Issuance

A. PSPP Holders

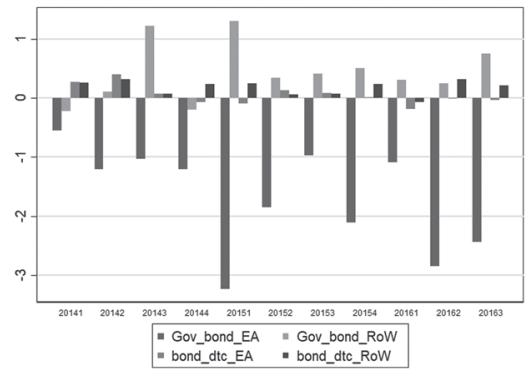

C. Non-PSPP Holders: Mixed Funds

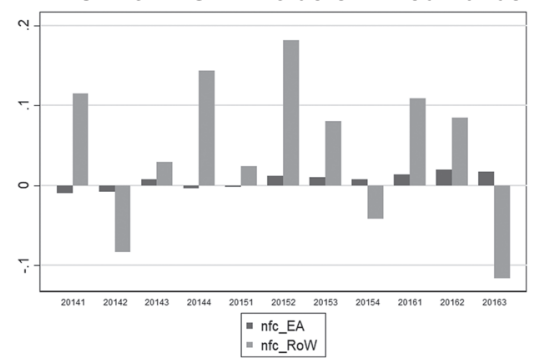

B. Non-PSPP Holders: Bond Funds

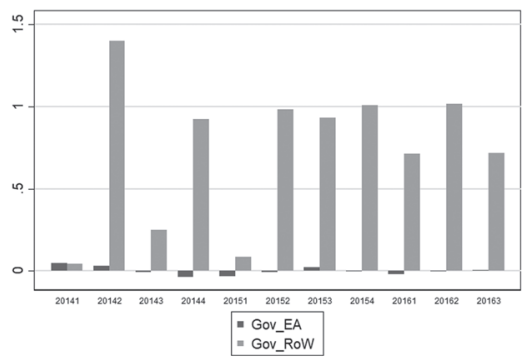

D. Non-PSPP Holders: Other Funds

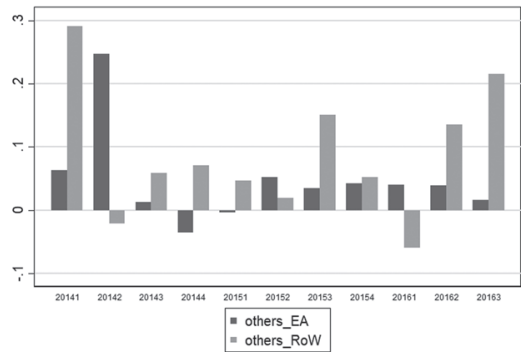

with QE dummies. In particular, funds with relatively large issuance of new units significantly rebalance their portfolios away from EAissued assets. Overall, there appears to be substantial evidence for rebalancing that may trigger an exchange rate adjustment channel (i.e., depreciation of the euro and increased imported inflation).

\subsubsection{Rebalancing by Maturity}

Table 14 shows panel regression results pertaining to the rebalancing across assets with different maturities for the case of PSPP-holding investment funds. This again shows a significantly negative parameter on the second QE dummy variable for the case of maturities covered by the program (maturity greater than two years). We see that there is statistically significant evidence of a move towards bonds with maturity less than two years in the first QE period.

In the case of non-PSPP-holding funds, we found evidence of rebalancing effects as follows. For the bond funds we found a consistently significant increase in holdings of government bonds (these 
Table 14. PSPP Sample: Net Purchases/Maturity

\begin{tabular}{|c|c|c|c|}
\hline Variables & less1year & less2year & more2year \\
\hline QE_antic & $\begin{array}{c}-1.316^{* *} \\
(0.619)\end{array}$ & $\begin{array}{l}0.259^{*} \\
(0.133)\end{array}$ & $\begin{array}{l}-0.626 \\
(1.020)\end{array}$ \\
\hline$Q E_{-}$first & $\begin{array}{l}0.0804 \\
(0.947)\end{array}$ & $\begin{array}{c}0.479^{* *} \\
(0.232)\end{array}$ & $\begin{array}{l}-1.051 \\
(1.410)\end{array}$ \\
\hline$Q E \_s e c o n d$ & $\begin{array}{l}-0.840 \\
(1.679)\end{array}$ & $\begin{array}{c}0.369 \\
(0.268)\end{array}$ & $\begin{array}{c}-3.577^{*} \\
(1.991)\end{array}$ \\
\hline Debt_net & $\begin{array}{l}-0.00140 \\
(0.00250)\end{array}$ & $\begin{array}{l}-0.000278 \\
(0.000477)\end{array}$ & $\begin{array}{c}-0.00944^{* *} \\
(0.00372)\end{array}$ \\
\hline US_long_yield & $\begin{array}{l}-0.944 \\
(1.503)\end{array}$ & $\begin{array}{c}0.466^{*} \\
(0.252)\end{array}$ & $\begin{array}{l}-0.572 \\
(2.009)\end{array}$ \\
\hline us_corp_spread2 & $\begin{array}{l}0.559^{* *} \\
(0.243)\end{array}$ & $\begin{array}{l}0.237^{* * *} \\
(0.0726)\end{array}$ & $\begin{array}{c}0.112 \\
(0.657)\end{array}$ \\
\hline$u s_{-} v i x \_v o l$ & $\begin{array}{c}0.0847 \\
(0.0718)\end{array}$ & $\begin{array}{l}-0.0164 \\
(0.0167)\end{array}$ & $\begin{array}{c}-0.0492 \\
(0.133)\end{array}$ \\
\hline L.dep & $\begin{array}{c}-0.295^{* * *} \\
(0.0652)\end{array}$ & $\begin{array}{c}-0.247^{* * *} \\
(0.0430)\end{array}$ & $\begin{array}{l}-0.0873 \\
(0.0800)\end{array}$ \\
\hline Observations & 1,338 & 1,338 & 1,343 \\
\hline Number of frfundkey & 174 & 174 & 174 \\
\hline AR1 p-value & 0.00131 & 0.00161 & 0.000172 \\
\hline AR2 p-value & 0.0155 & 0.0891 & 0.0866 \\
\hline Hansen-J p-value & 0.177 & 0.0339 & 0.281 \\
\hline Wald p-value & $1.24 \mathrm{e}-07$ & $4.99 \mathrm{e}-10$ & 0.000359 \\
\hline
\end{tabular}

are non-PSPP bonds by definition) with maturity greater than two years. For funds classed as "other" we also find a positive and significant increase in holdings of assets with maturity greater than two years. These results are supportive of QE effects working through investor preferences for assets with greater average duration (and some additional yield). This should contribute to a flattening of the term structure and an improvement in long-term funding costs for both the public and private sectors. Hedge, mixed, and real estate funds never provide significant results. 


\section{Robustness Analysis}

A number of robustness checks were carried out. Firstly, we examined a number of alterations in the lag structure of the ArellanoBover GMM specification. We found that results were stable for the use of lags as instruments for the case of (i) lags 2 and 3, (ii) lags 2,3 , and 4 , or (iii) lags 2 to 5 . In many cases there is actually quite weak evidence for the need for a lagged dependent variable in the regression. This suggests that a static panel could be used as an alternative to the GMM approach. We found that (for the basic model without the interaction with fund characteristics) many of the core results discussed above survive when we move to a static fixed-effects panel regression method. Specifically, the evidence of a move by PSPP holders from PSPP assets to those issued by deposittaking corporates remains significant. We had some concern that our PSPP sample of funds could contain many funds that are strictly mandated to only invest in PSPP assets. However, even when we dropped funds with consistently over 90 percent of their portfolio in EA-issued government bonds, the results remained broadly similar (i.e., coefficients changed slightly but signs and significance remained the same).

As regards the sample of funds that had been dropped from the main analysis due to extremely high daily turnover, we carried out all of the same regressions as discussed above on this sample to ensure that we were not losing important information. We found some similar results for such funds but, more often than not, the results lacked consistent statistical significance. This reflects the fact that the sample of funds in this category is quite small, is diverse in behaviors, and the number of parameters being estimated is relatively large (especially in the specifications that includes interaction terms). There is however evidence of a statistically significant increase in investment in Bonds_other in the standard regression without interaction terms for the PSPP-holding high-turnover funds in anticipation of QE and, even more so, for the first and second QE phases. Together with the negative sign (albeit statistically insignificant) on all the QE dummies for Bonds_gov, this can be regarded as valid evidence for a rebalancing from PSPP assets to non-PSPP assets. PSPP-holding high-turnover funds also tend to show a move towards holding short-term securities (this is into securities outside 
the purchasable basket). The results for the non-PSPP high-turnover funds do not provide significant evidence of rebalancing, but in this case there is some evidence of increased redemptions and decreased issuance of fund units across the QE periods.

\section{Conclusion}

We have examined the portfolio rebalancing behavior of a large sample of investment funds before and during the Eurosystem's Public Sector Purchase Programme (PSPP). We find evidence that funds most exposed to the purchase program rebalanced their portfolios towards bonds issued by deposit-taking corporations, into assets with maturities outside the maturities eligible for purchase under the program, and away from euro-denominated assets. For subsets of funds focused on non-PSPP eligible assets, we found evidence of moves into longer-term securities and away from euro-denominated assets.

Via an examination of redemptions and issues by funds of their own shares (units), we found that investors rebalanced away from PSPP-holding funds towards those focused on holding other types of assets. This probably reflects an increase in investment in the nonPSPP fund sector, those specializing in bonds that can give investors similar exposure to what they would usually obtain from investment in units of PSPP-holding funds. Investor rebalancing behavior interacts significantly with portfolio rebalancing behavior of the funds themselves.

Overall, our analysis provides support for rebalancing effects, but it seems that these are mostly towards assets issued outside the euro area. In economic terms (based on the size of net purchases), the effects do not appear large. Given that we only find significant effects after the pace of purchases was increased, the choice of program scale may be crucial. There is no evidence of rebalancing towards equities, which supports the views of Ball et al. (2017) that extending the purchase program in this direction may be beneficial. At the time of the announcement of the purchase program, equities rose significantly, but it has been shown that this was due mostly to a perceived lower discount rate over an extended future horizon. The associated drop in the cost of capital should have produced issuance of new equity. But we see no sign of this in fund portfolios. This 
sector, during the sample, may have been holding off until issuance conditions improved. The same could be said of banks, since we also find little evidence of rebalancing towards EA bonds or equities issued by the deposit-taking corporations.

As with equity valuation, it might be expected that our findings of continued portfolio rebalancing towards non-EA assets may have helped to generate euro weakness. We know however, from other research, that the bulk of euro weakening over this entire period can be linked to the initial announcement of the program itself. Continued flow towards non-EA assets during the sample period, despite euro weakness, suggests a reluctance on the part of investors (both funds and fund investors) to bet on growth prospects given perceived risks.

Our sample period ends in the third quarter of 2016. Recent developments, visible from sector-based asset holdings, seem to indicate some strengthening of effects from the asset purchase program. These include (i) an improvement in net external assets, (ii) a rebalancing towards European equities, and (iii) a significant increase in investors' preferences for debt securities issued by euro-area banks. Whether these developments are attributable particularly to asset purchases is open to question, and this therefore remains an important avenue for a possible future extension of the current analysis.

\section{References}

Albertazzi, U., B. Becker, and M. Boucinha. 2016. "Portfolio Rebalancing and the Transmission of Large-Scale Asset Programs: Evidence from the Euro Area." Working Paper (November).

Altavilla, C., M. Boucinha, and J.-L. Peydró. 2017. "Monetary Policy and Bank Profitability in a Low Interest Rate Environment." ECB Working Paper No. 2105 (October).

Altavilla, C., F. Canova, and M. Ciccarelli. 2016. "Mending the Broken Link: Heterogeneous Bank Lending and Monetary Policy Pass-through." ECB Working Paper No. 1978 (November).

Altavilla, C., G. Carboni, and R. Motto. 2015. "Asset Purchase Programmes and Financial Markets: Lessons from the Euro Area." ECB Working Paper No. 1864. 
Altavilla, C., M. Pagano, and S. Simonelli. 2017. "Bank Exposures and Sovereign Stress Transmission." Review of Finance 21 (6): 2103-39.

Andrade, P., J. Breckenfelder, F. De Fiore, P. Karadi, and O. Tristani. 2016. "The ECB's Asset Purchase Programme: An Early Assessment." ECB Working Paper No. 1956 (September).

Andrade, P., C. Cahn, H. Fraisse, and J.-S. Mésonnier. 2017. "Can the Provision of Long-Term Liquidity Help to Avoid a Credit Crunch? Evidence from the Eurosystem's LTRO." Working Paper.

Arellano, M., and S. Bond. 1991. "Some Tests of Specification for Panel Data: Monte Carlo Evidence and an Application to Employment Equations." Review of Economic Studies 58 (2): 277-97.

Arellano, M., and O. Bover. 1995. "Another Look at the Instrumental Variable Estimation of Error-Components Models." Journal of Econometrics 68 (1): 29-51.

Bai, J., and S. Ng. 2010. "Instrumental Variables Estimation in a Data Rich Environment." Econometric Theory 26 (6): 15771606.

Ball, L., J. Gagnon, P. Honohan, and S. Krogstrup. 2017. "What Else Can Central Banks Do?" CEPR \& ICMB Geneva Reports on the World Economy No. 18.

Baum, C., M. E. Schaffer, and S. Stillman. 2003. "Instrumental Variables and GMM: Estimation and Testing." Stata Journal 3 (1): $1-31$.

Baumeister, C., and L. Benati. 2013. "Unconventional Monetary Policy and the Great Recession: Estimating the Macroeconomic Effects of a Spread Compression at the Zero Lower Bound." International Journal of Central Banking 9 (2): 165-211.

Benford, J., S. Berry, K. Nikolov, M. Robson, and C. Young. 2009. "Quantitative Easing." Quarterly Bulletin (Bank of England) Q2 (June 12): 90-100.

Bergant, K. 2017. "Quantitative Easing and Portfolio Rebalancing: Micro Evidence from Irish Resident Banks." Economic Letter No. 7, Central Bank of Ireland.

Blundell, R., and S. Bond. 1998. "Initial Conditions and Moment Restrictions in Dynamic Panel Data Models." Journal of Econometrics 87 (1): 115-43. 
Bollerslev, T., G. Tauchen, and H. Zhou. 2009. "Expected Stock Returns and Variance Risk Premia." Review of Financial Studies 22 (11): 4463-92.

Brunnermeier, M. K., and Y. Sannikov. 2014. "A Macroeconomic Model with a Financial Sector." American Economic Review 104 (2): $379-421$.

Bubeck, J., M. M. Habib, and S. Manganelli. 2017. "The Portfolio of Euro Area Fund Investors and ECB Monetary Policy Announcements." ECB Working Paper No. 2116 (December).

Carpenter, S., S. Demiralp, J. Ihrig, and E. Klee. 2013. "Analyzing Federal Reserve Asset Purchases: From Whom Does the Fed Buy?" Finance and Economics Discussion Series No. 2013-32, Board of Governors of the Federal Reserve System.

- 2015. "Analyzing Federal Reserve Asset Purchases: From Whom Does the Fed Buy?" Journal of Banking and Finance 52 (March): 230-44.

Carpinelli, L., and M. Crosignani. 2017. "The Effect of Central Bank Liquidity Injections on Bank Credit Supply." Finance and Economics Discussion Series No. 2017-038, Board of Governors of the Federal Reserve System.

Christensen, J., and G. Rudebusch. 2012. "The Response of Interest Rates to US and UK Quantitative Easing." Economic Journal 122 (564): F385-F414.

Coimbra, N., and H. Rey. 2016. "Financial Cycles with Heterogeneous Intermediaries." Working Paper, London Business School. D'Amico, S., W. English, D. López-Salido, and E. Nelson. 2012. "The Federal Reserve's Large-Scale Asset Purchase Programs: Rationale and Effects." Economic Journal 122 (564): F415-F446.

D'Amico, S., and T. King. 2013. "Flow and Stock Effects of LargeScale Treasury Purchases: Evidence on the Importance of Local Supply." Journal of Financial Economics 108 (2): 425-48.

Demertzis, M., and G. B. Wolff. 2016. "The Effectiveness of the European Central Bank's Asset Purchase Programme." Bruegel Policy Contribution.

DeSantis, R. A., and F. Holm-Hadulla. 2017. "Flow Effects of Central Bank Asset Purchases on Euro Area Sovereign Bond Yields: Evidence from a Natural Experiment." ECB Working Paper No. 2052 . 
Deutsche Bundesbank. 2017. "The Eurosystem's Bond Purchases and the Exchange Rate of the Euro." Monthly Report 69 (1): $13-39$.

Eggertsson, G. B., and M. Woodford. 2003. "The Zero Bound on Interest Rates and Optimal Monetary Policy." Brookings Papers on Economic Activity 34 (1): 139-211.

Engen, E. M., T. Laubach, and D. Reifschneider. 2015. "The Macroeconomic Effects of the Federal Reserve's Unconventional Monetary Policies." Finance and Economics Discussion Series No. 2015-005, Board of Governors of the Federal Reserve System.

Eser, F., and B. Schwaab. 2016. "Evaluating the Impact of Unconventional Monetary Policy Measures: Empirical Evidence from the ECB's Securities Markets Programme." Journal of Financial Economics 119 (1): 147-67.

European Central Bank. 2013. "Box 3: Early Repayment of Funds Raised through Three-year Longer-term Refinancing Operations: Economic Rationale and Impact on the Money Market." Economic Bulletin (February): 30-31.

2015. "Box 2: Recent Equity Price Developments in the Euro Area and the United States." Economic Bulletin 4 (January): 34-38.

Fratzscher, M., M. Lo Duca, and R. Straub. 2016. "ECB Unconventional Monetary Policy: Market Impact and International Spillovers." IMF Economic Review 64 (1): 36-74.

Gagnon, J., M. Raskin, J. Remache, and B. Sack. 2010. "Large-scale Asset Purchases by the Federal Reserve: Did They Work?" Staff Report No. 411, Federal Reserve Bank of New York.

- 2011. "The Financial Market Effects of the Federal Reserve's Large-scale Asset Purchases." International Journal of Central Banking 7 (1): 3-43.

Glick, R., and S. Leduc. 2013. "The Effects of Unconventional and Conventional US Monetary Policy on the Dollar." Working Paper No. 2013-11, Federal Reserve Bank of San Francisco.

Haldane, A., M. Roberts-Sklar, T. Wieladek, and C. Young. 2016. "QE: The Story So Far." CEPR Discussion Paper No. 11691.

Hau, H., and S. Lai. 2016. "Asset Allocation and Monetary Policy: Evidence from the Eurozone." Journal of Financial Economics 120 (2): 309-29. 
Hogen, Y., and M. Saito. 2014. "Portfolio Rebalancing Following the Bank of Japan's Government Bond Purchases: Empirical Analysis Using Data on Bank Loans and Investment Flows." Research Paper No. 14-06-19 (June), Bank of Japan.

Holtz-Eakin, D., W. Newey, and H. Rosen. 1988. "Estimating Vector Autoregressions with Panel Data." Econometrica 56 (6): 137195.

Joyce, M., A. Lasaosa, I. Stevens, and M. Tonks. 2011. "The Financial Market Impact of Quantitative Easing in the United Kingdom." International Journal of Central Banking 7 (3): 113-61.

Joyce, M., Z. Liu, and I. Tonks. 2015. "Institutional Investor Portfolio Allocation, Quantitative Easing and the Global Financial Crisis." Working Paper No. 510 (September), Bank of England. Joyce, M., and M. Tonks. 2012. "QE and the Gilt Market: A Disaggregated Analysis." Economic Journal 122 (564): F348-F384.

Koijen, R. S. J., F. Koulischer, B. Nguyen, and M. Yogo. 2017. "Euro-area Quantitative Easing and Portfolio Rebalancing." American Economic Review 107 (5): 621-27.

Krishnamurthy, A., and A. Vissing-Jorgensen. 2011. "The Effects of Quantitative Easing on Interest Rates: Channels and Implications for Policy." Brookings Papers on Economic Activity 42 (2, Fall): $215-87$.

Stein, J. C. 2014. "Incorporating Financial Stability Considerations into a Monetary Policy Framework." Remarks at the International Research Forum on Monetary Policy, Washington, DC, March 21.

Valiante, D. 2015. "The 'Visible Hand' of the ECB's Quantitative Easing." CEPS Working Paper No. 407 (May).

Vayanos, D., and J.-L. Vila. 2009. "A Preferred-habitat Model of the Term Structure of Interest Rates." Discussion Paper No. 641, Financial Markets Group, London School of Economics and Political Science.

Weale, M., and T. Wieladek. 2014. "What Are the Macroeconomic Effects of Asset Purchases?" Discussion Paper No. 42, Bank of England.

Windmeijer, F. 2005. "A Finite Sample Correction for the Variance of Linear Efficient Two-step GMM Estimators." Journal of Econometrics 126 (1): 25-51.

Woodford, M. 2012. "Inflation Targeting and Financial Stability." NBER Working Paper No. 17967. 